\title{
Revision of Chinese mainland Hybovalgus Kolbe, 1904, with description of a new species, and Excisivalgus Endrödi, 1952 reduced to synonymy with Hybovalgus (Coleoptera: Scarabaeidae)
}

\author{
Enrico RICCHIARDI ${ }^{1, *} \&$ Sha LI $^{2}$ \\ ${ }^{1}$ Corso A. Tassoni 79/4, 10143 Torino, Italy.
}

${ }^{2}$ Key Laboratory of Zoological Systematics and Evolution, Institute of Zoology, Chinese Academy of Sciences, Box 92, Beichen West road, Chaoyang District, Beijing, 100101, China; University of the Chinese Academy of Sciences, Yuquan road, Shijingshan, Beijing, 100039, China.

*Corresponding author: alericor@fastwebnet.it ${ }^{2}$ Email: 545407454@qq.com

${ }^{1}$ urn:Isid:zoobank.org:author:F09BCF76-35DE-4821-91C4-EEDC5114810A

${ }^{2}$ urn:1sid:zoobank.org:author:2DE7F73C-A515-418C-A2AC-5394D5AB44C1

\begin{abstract}
The genus Hybovalgus Kolbe, 1904 is represented by eight species on the Chinese mainland, many of which also inhabit northern Vietnam and Laos. Species of Hybovalgus are endemic to this area, and to the island of Taiwan. Until now, there is a lot of confusion in our knowledge of Hybovalgus on mainland China, due to erroneous descriptions of new species by European entomologists and incorrect identifications of specimens by local entomologists. Study of more material and many types has clarified this situation by better defining the species, synonymizing some of them, describing one new species, Hybovalgus calvus sp. nov. and recognizing the fact that females of two species were included in the new genus Excisivalgus Endrödi, 1952, which is here synonymized with Hybovalgus.
\end{abstract}

Keywords. Cetoniinae, Hybovalgus, Excisivalgus, new synonym, new species.

Ricchiardi E. \& Li S. 2017. Revision of Chinese mainland Hybovalgus Kolbe, 1904, with description of a new species, and Excisivalgus Endrödi, 1952 reduced to synonymy with Hybovalgus (Coleoptera: Scarabaeidae). European Journal of Taxonomy 340: 1-32. https://doi.org/10.5852/ejt.2017.340

\section{Introduction}

In the appendix of his study on valgines, Kolbe (1904) proposed the genus Hybovalgus based on a single species from northern Vietnam, Hybovalgus bioculatus Kolbe, 1904. The new genus, according to its author, could be separated from his other new genus, Dasyvalgus Kolbe, 1904, by several characters (Kolbe 1904: 55-57) that actually applied only to H. bioculatus.

After the original description of Hybovalgus, several new species were included in the genus. Schenkling (1922) listed the following seven species described by Kolbe or by Moser: H. bioculatus Kolbe, 1904; H. fraternus Moser, 1915; H. fulvosquamosus Moser, 1904; H. thoracicus Moser, 1911; 
H. tonkinensis Moser, 1904; H. versicolor Moser, 1908 and H. yunnanus Moser, 1906. The latter two species were reported from Yunnan, the first records of Hybovalgus in China. A third Chinese species, Valgus thibetanus Nonfried, 1891, not recognized in Schenkling (1922) as Hybovalgus, was included in Hybovalgus by Krajčík (2011).

Arrow (1944) described another new species of Hybovalgus from Shandong Province, China: Hybovalgus laticollis Arrow, 1944. After that, no other species of Chinese Hybovalgus were described.

In the most recent list of Chinese Valgini (sensu Krikken 1984), Krajčík (2011) reported the following Hybovalgus species in China:

- H. fraternus, North Vietnam and possibly China;

- H. laticollis, Weihaiwei (Shandong);

- H. thibetanus, Xizang, Yunnan, Sichuan, Shaanxi;

- H. tonkinensis, North Vietnam and reported to be present in Fujian;

- H. versicolor (Yunnan), stated as: "most probably a junior synonym (+) of H. thibetanus";

- H. yunnanus (Yunnan).

Before Krajčík (2011), Ma (1995) listed three Hybovalgus species from China: H. thoracicus, $H$. bioculatus and $H$. sexdentatus Arrow, 1944. After careful examination of the specimens now preserved at IZAS, S. Li found that two species had been misidentified: H. thoracicus sensu Ma (1995) is actually a female of $H$. tonkinensis and H. bioculatus sensu Ma (1995) is actually Hybovalgus thibetanus. Ma's determination of Hybovalgus sexdentatus was correct; therefore, this species should be added to the list of Krajčík (2011).

We studied most of the types of species belonging to the subtribe Valgina (sensu Smith et al. 2006) species described from China and preserved at AMNH, ERC, HNHM, IZAS, MHNG, MNHN, MNHUB, NHM, SNMS, ZFMK, and ZMUC. We found some generic misplacements by several authors and numerous synonyms since those new species had not been compared with types. In addition, two other events contributed to these errors:

1) Some types were collected in the early $20^{\text {th }}$ century by French missionaries operating in northwestern China, close to the Tibetan border. Because of inexact knowledge of the borders between Tibet and China at that time, some specimens were labelled as "Tibet" or "Thibet", but they may have come from northwestern Sichuan or north Yunnan provinces.

2) As often happens in Valgina (e.g., Ricchiardi \& Li 2015), few females were collected, which are morphologically different from males in some features and often difficult to associate with males. This is why Endrödi (1952) described a new Valgina genus, Excisivalgus Endrödi, 1952, with two new species, Excisivalgus csikii Endrödi, 1952 and Excisivalgus klapperichi Endrödi, 1952. These two species are here recognized as the females of two previously described Hybovalgus species.

\section{Materials and methods}

Most of the type specimens of species discussed in this paper were examined and are detailed under the taxonomy section of each species.

The total length of a specimen was measured from the anterior margin of the pronotum to the apex of the pygidium (including the protrusion at the apex of the pygidium present in some females). Specimen width is the maximum width across the elytra. Measurements were taken using the millimeter grid of a binocular microscope.

Photographs of holotypes were taken with a Nikon Coolpix P7700 attached to one of the eyepieces of a Wild dissecting microscope or with the same camera, but without the microscope. Photographs were 
processed with photo stacking software (Zerene Stacker, Version 1.04 Build T201411272115; http:// www.zerenesystems.com). Finally, in order to increase clarity, backgrounds were removed from photos using GIMP 2.8.14.

We refer to Ricchiardi \& Li (2015) for some morphological terms.

Photographs of the mating couple and types of Hybovalgus tonkinensis were taken with a Canon EOS 5D Mark III and MP-E 65mm f/2.8 1-5× lens (see Fig. 2).

The following abbreviations are used to denote specimen depositories:

$\mathrm{AMNH}=$ American Museum of Natural History, New York, U.S.A.

ERC $=$ Enrico Ricchiardi Collection, Turin, Italy

HNHM = Hungarian Natural History Museum, Budapest, Hungary

IZAS = Institute of Zoology, Chinese Academy of Science, Bejing, China

MHNG = Musée d'Histoire Naturelle, Geneva, Switzerland

MNHN = Muséum national d'Histoire naturelle, Paris, France

MNHUB $=$ Museum für Naturkunde, Berlin, Germany

NHM $=$ The Natural History Museum (formerly British Museum of Natural History), London, U.K.

SNMS $=$ Staatliches Museum für Naturkunde, Stuttgart, Germany

ZFMK = Zoologisches Forschungsinstitut und Museum Alexander König, Bonn, Germany

ZMUC = Zoological Museum University of Copenhagen, Denmark

The following abbreviations are used to denote types:

$\mathrm{LT}=$ Lectotype

$\mathrm{HT}=$ Holotype

PLT $=$ Paralectotype

$\mathrm{PT}=$ Paratype

$\mathrm{ST}=$ Syntype

$\mathrm{TY}=$ Type

\section{Results}

\section{Nomenclatural acts}

The following nomenclatural acts are presented:

Excisivalgus Endrödi, 1952 syn. nov. is placed as a junior synonym of Hybovalgus Kolbe, 1904.

Hybovalgus calvus sp. nov. is described as a new species.

Excisivalgus csikii Endrödi, 1952 syn. nov. is placed as a junior synonym of Hybovalgus fraternus Moser, 1915.

Hybovalgus fulvosquamosus Moser, 1904, type series designation.

Hybovalgus jordansi (Endrödi ,1952) comb. nov., new combination.

Hybovalgus laticollis Arrow, 1944 syn. nov.; Hybovalgus yunnanus Moser, 1906 syn. nov.; Dasyvalgus pubicollis Pic, 1928 syn. nov. and Valgus savioi Pic, 1928 syn. nov. are placed as junior synonyms of Hybovalgus thibetanus (Nonfried, 1891).

Hybovalgus thibetanus (Nonfried, 1891), type series designation.

Hybovalgus yunnanus Moser, 1906, type series designation.

Valgus savioi Pic, 1928, type series designation.

Dasyvalgus pubicollis Pic, 1928, type series designation.

Excisivalgus klapperichi Endrödi, 1952 syn. nov. is placed as a junior synonym of Hybovalgus tonkinensis Moser, 1904.

Hybovalgus tonkinensis Moser, 1904, type series designation. 
Hybovalgus versicolor Moser 1908 syn. nov. is placed as a junior synonym of Hybovalgus thibetanus (Nonfried, 1891).

Hybovalgus versicolor Moser 1908, type series designation.

Homovalgus seticollis Kolbe, 1897, re-establishement of combination.

A key for each sex of Chinese mainland Hybovalgus is included in this work.

\author{
Class Insecta Linnaeus, 1758 \\ Order Coleoptera Linnaeus, 1758 \\ Superfamily Scarabaeoidea Latreille, 1802 \\ Family Scarabaeidae Latreille, 1802 \\ Subfamily Cetoniinae Leach, 1815 \\ Tribe Valgini Mulsant, 1842
}

Subtribe Valgina Mulsant, 1842 (Bouchard et al. 2011)

\title{
Checklist of Chinese Hybovalgus
}

Hybovalgus bioculatus Kolbe, 1904

calvus sp. nov.

fraternus Moser, 1915

= Excisivalgus csikii Endrödi, 1952

fulvosquamosus Moser, 1904

sexdentatus Arrow, 1944

jordansi (Endrödi, 1952)

thibetanus (Nonfried, 1891)

= versicolor Moser, 1908

= laticollis Arrow, 1944

= Valgus pubicollis Pic, 1928

= Valgus savioi (Pic, 1928)

= yunnanus Moser, 1906

tonkinensis Moser, 1904

= Excisivalgus klapperichi Endrödi, 1952

\section{Key to males}

1. Pronotal carinae present as rounded elevations or barely noticeable

- Pronotal carinae sharp (sometimes only slightly sharp) …...........................................................

2. Pronotal posterior margin slightly protruding backwards, apex rounded

- Pronotal posterior margin simply rounded

H. bioculatus Kolbe, 1904

3. Pronotal carinae parallel, barely noticeable or nearly obsolete, short or long (at most $1 / 3$ pronotal length). Meso- and metatibiae each without central tooth on posterior sides

H. calvus sp. nov.

- Pronotal carinae arched outwardly, ending well after middle of disc. Meso- and metatibiae each with a prominent central tooth on posterior side

H. tonkinensis Moser, 1904

4. Protibia with 6 external teeth: teeth 1-3 long and sharp, teeth 4-6 short and slightly sharp

- Protibia with 5 external teeth: teeth 1-3 long and sharp, teeth 4-5 short and slightly sharp 
5. Posterior margin of pronotum simply rounded; pronotal lateral margin not arched toward inside on posterior half

- Posterior margin of pronotum at center more or less prominent; pronotal lateral margins noticeably arched on posterior toward inside in the second half

6. Pronotum suboval (Fig. 7A), lateral small carina obsolete. Anal sternites covered with recumbent, testaceous scales, sparse on disc and dense laterally

H. fraternus Moser, 1915

- Pronotum subtrapezoidal (Fig. 9A), lateral small carina present, posteriorly arching outwards. Anal sternites completely covered with thick, recumbent, testaceous scales

H. thibetanus (Nonfried, 1891)

7. Pronotal posterior margin at center slightly prominent, with apex rounded (Fig. 8K); pronotal lateral small carina obsolete

H. fulvosquamosus Moser, 1904

- Pronotal posterior margin at center prominent, V-shaped, apex rounded on top only (Fig. 8G); pronotal lateral small carina present, posteriorly arching outwards

H. jordansi (Endrödi, 1952)

Key to females (females of $H$. fulvosquamosus and $H$. jordansi are unknown)

1. Pronotal carinae present as rounded elevations or noticeable and short ...... 2

- Pronotal carinae sharp (sometimes only slightly sharp)

2. Pronotal posterior margin at center excavated in shape of an enlarged "E". Metatibia without central tooth at center of posterior margin

H. bioculatus Kolbe, 1904

- Pronotal posterior margin at center prominent, V-shaped. Metatibia with a barely noticeable tooth at center of posterior margin

H. calvus sp. nov.

3. Protibia with 5 external teeth

- Protibia with 6 external teeth

H. sexdentatus Arrow, 1944

4. Pronotal posterior margin at center deeply excavated as an enlarged "E" (Fig. 11E)

H. tonkinensis Moser, 1904

- Pronotal posterior margin at center slightly excavated as an enlarged "C" (Fig. 9G) ......... 5

5. Elytra near scutellum deeply depressed and with prominent ridges. Pygidium without cretaceous maculae

H. thibetanus (Nonfried, 1891)

- Elytra near scutellum depressed but without ridges. Pygidium on sides covered with cretaceous maculae H. fraternus Moser, 1915

\section{Hybovalgus Kolbe, 1904}

Hybovalgus Kolbe, 1904: 55.

Excisivalgus Endrödi, 1952: 62, syn. nov.

\section{Type species}

Hybovalgus bioculatus Kolbe, 1904 by monotypy.

\section{Diagnosis}

In the years after 1904 some entomologists tried to better define Hybovalgus (Arrow 1944; Paulian 1961; Krikken 1978; Miyake 1985), but could not find even one morphological synapomorphy. Krikken (1984) and Miyake (1985) wrote that the shape of the parameters was peculiar to Hybovalgus. Miyake (1985) distinguished Hybovalgus from Dasyvalgus as follows: "Parameres more or less prolonged, not confluent 
each other, with a excision on each inner edge, Hybovalgus. Parameres vestigial, sometimes confluent each other, Dasyvalgus". The paramere shape of each genus is different, and easily distinguishable, although the meaning given to the word "vestigial" by Miyake is not clear.

After studying many specimens (including all the species of Hybovalgus in Taiwan), we conclude that the males of Hybovalgus can be distinguished from those of Dasyvalgus by a series of non-exclusive characters and by the shape of the parameres (Fig. 3A-F). The special shape of Hybovalgus parameres is distinctive compared with the variable parameres of males of Dasyvalgus species. This paramere shape, that we define as "Hybovalgus shape", within the Chinese Valgina is shared only with Dasyvalgoides denticulatus Endrödi, 1952, in a monotypic genus. The relationship between these two genera must still be investigated, but the latter species is readily distinguishable from any Hybovalgus by the protibia with six teeth; and from $H$. sexdentatus by its flattened body with inconspicuous scales tufts.

The series of non-exclusive characters that separate Hybovalgus from the other Oriental Valgina genera are:

- Protibial external teeth 1-3 long and sharp in males, where tooth 2 is sometime a bit shorter than 1 and 3 ; the same for females but often they are worn by digging (see remarks on page 7 about differences between the two sexes) and in some cases tooth 2 is slightly shorter than 1 or 3 (Fig. 1).

- Both sexes have 5-6 protibial teeth.

- Suctorial brush long in males, short in females (Ricchiardi \& Li 2015). See remarks below about differences between the two sexes.

- Anterior margin of clypeus noticeably sinuate in both sexes, a bit less in females of $H$. thibetanus.

- Pronotal lateral margins more or less crenate in both sexes.

- Pronotal lateral margin depression always present in both sexes.

- Pronotal posterior margin of most females (but not all) more or less excavated.

- Parameres of Hybovalgus shape (Fig. 3).
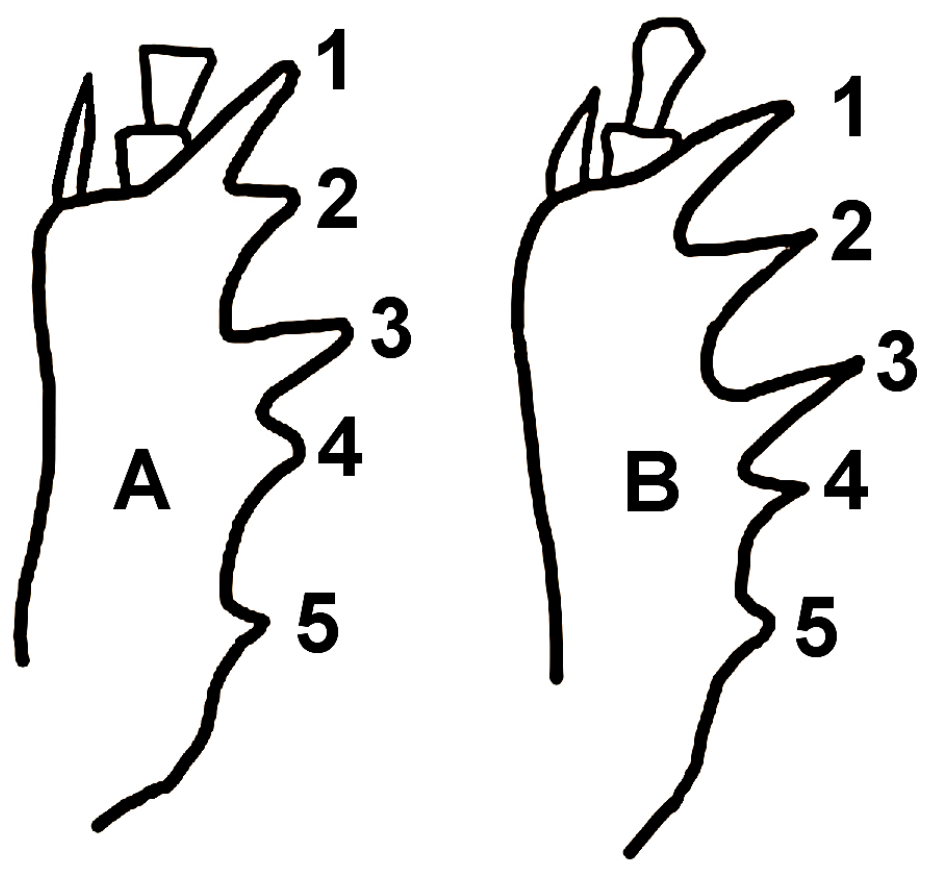

Fig. 1. Five-toothed protibia. A. LT of Hybovalgus fraternus Moser, 1915 (MNHUB). B. LT $\widehat{\partial}$ of Hybovalgus fulvosquamosus Moser, 1904 (MNHUB). 
- Protibia with five teeth on the external margin, in one case six (H. sexdentatus).

- Pygidium of males always narrowed from the middle to the apex; apex rounded in caudal view, not prominent in lateral view. Pygidium of females often (but not always) modified at apex (see Remarks under species accounts below).

- Pygidium of males with a ventral small, flat or slightly hollowed surface with posterior margin rounded or pointed at center. In females this area is bigger and deeply hollowed.

- Pygidium of females without pygidial stylus.

- Propygidial scale tufts of females darker than those of males.

Some species have protibial teeth 1-2 and/or 3-4 closer to one another than to the others. This character is not consistent among all the specimens of Hybovalgus as it varies within the same species.
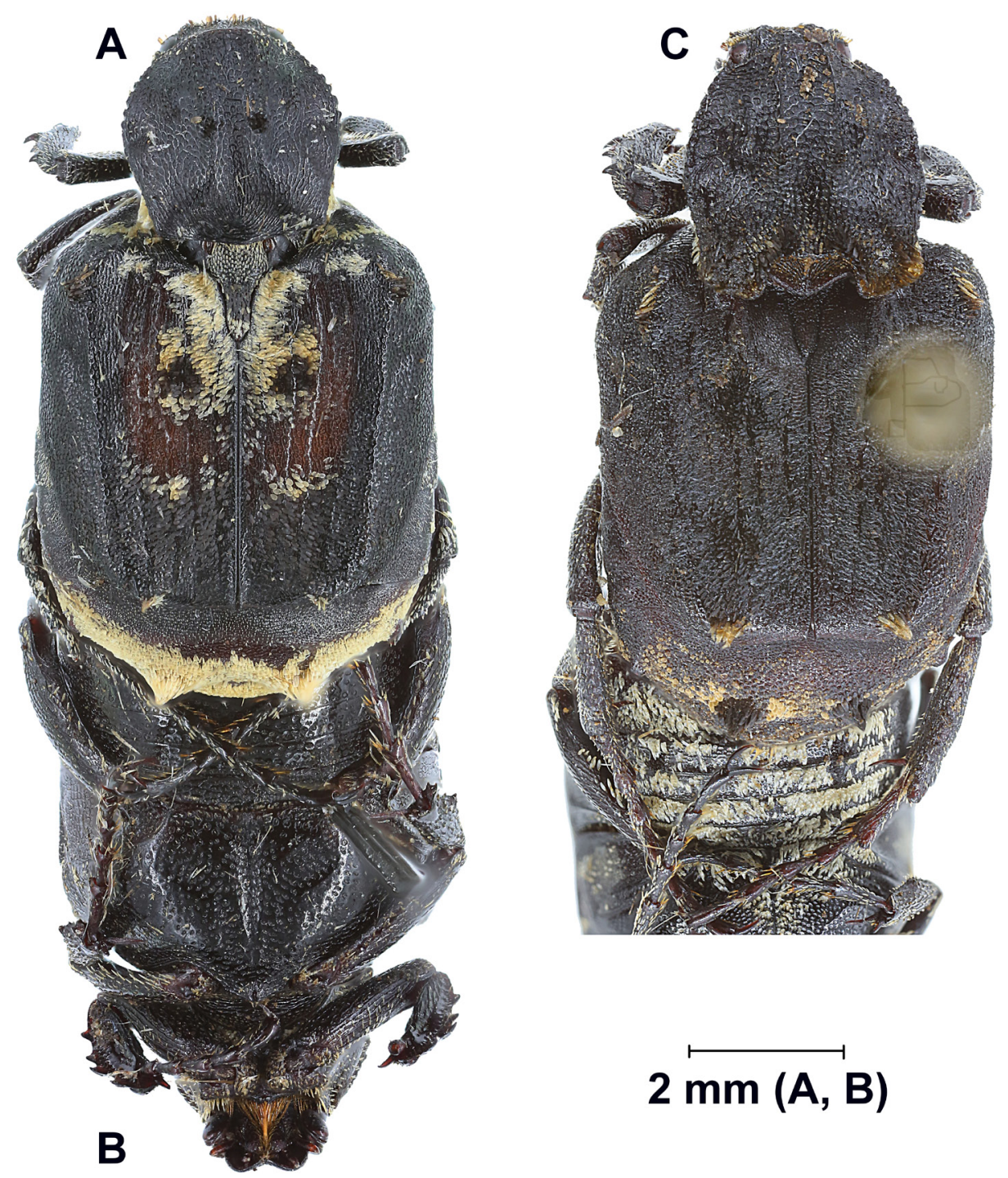

Fig. 2. Mating pair of Hybovalgus tonkinensis Moser, 1904, from Fujian (IZAS). A. §. B- C. . . 
Another character that we decided not to use for the separation of species is the presence or absence of cretaceous maculae on the propygidium or pygidium of males. In some species those maculae are really difficult to see because they are covered with thick scales or by the built-up body grease.

\section{Identification of females}

Generally, it is easy to separate females from males because the pronotal posterior margin is more or less deeply excavated ( $H$. bioculatus, $H$. fraternus, $H$. thibetanus, $H$. tonkinensis) and/or the apex of the pygidium is modified into a pointed projection (H. fraternus, $H$. sexdentatus, $H$. thibetanus, H. tonkinensis), a rounded projection (H. bioculatus), or the apex is simply rounded (H. calvus sp. nov.).

Often, females are larger than males. All the females we studied bear black propygidial scale tufts, even when their male counterparts have testaceous propygidial scale tufts.

Females of two species, H. fulvosquamosus and H. jordansi, are unknown.

\section{Variability of paramere shape}

After analysis of the males of a many Valgina belonging to hundreds of species, we concluded that the study of the shape of the parameres is a reliable way to define species. There are, however, a couple of notable exceptions. Jameson \& Swoboda (2005), revising the New World Valgina, wrote that: "However, one species of New World valgine, Valgus seticollis Beauvois, 1807, has extremely variable male genitalia although there is an overall similarity in pattern" (Jameson \& Swoboda 2005: figs 31-35); "Other characters that we examined are consistent within this species, including form of the tarsomeres, pygidial spine, pronotum, sternites, and spiracles. Lacking other morphological characters to separate the genitalic forms, we conservatively group all the forms as one species. A thorough study of the genitalic forms of $V$. seticollis would be an excellent topic for a molecular analysis and could reveal interesting evolutionary patterns".

Kolbe (1897) described a new Valgina genus, Homovalgus, to include Valgus seticollis. Jameson \& Swoboda (2005) clarified the nomenclature of the species and placed it under Valgus. It is our opinion that because the shape of the parameres is similar to that of Hybovalgus/Dasyvalgoides, and the lack of a pygidial stylus in females, this species must be separated from Valgus and that its valid name is Homovalgus seticollis. The relationships of this species to the Oriental Valgina could add appeal to further study.

In the Oriental Region, another species, Hybovalgus fraternus, is a similar case to that of Homovalgus seticollis. Hybovalgus fraternus also exhibits limited variation in morphology and great variation in paramere shape. This is why we decided to conservatively avoid splitting this species merely on the basis of variation in paramere shape.

\section{Description of aedeagus}

Figure 3 shows several examples of the aedeagus of Chinese Hybovalgus species along with some nomenclature. The outline of the aedeagus is distinctive. The phallobase is always V-shaped ventroapically (vs) and with a sclerotized upper anterior part ( $\mathrm{spb}$ ) notched, flat or pointed, sometime variable within the same species. The parameres are prominent, with the apex extended and with different shapes, with or without a sub-apical external or internal tooth; basal lobe more or less developed and in some cases variable in shape within a species. In lateral view the parameres shows a more or less deep, basomedial notch (bmn). 

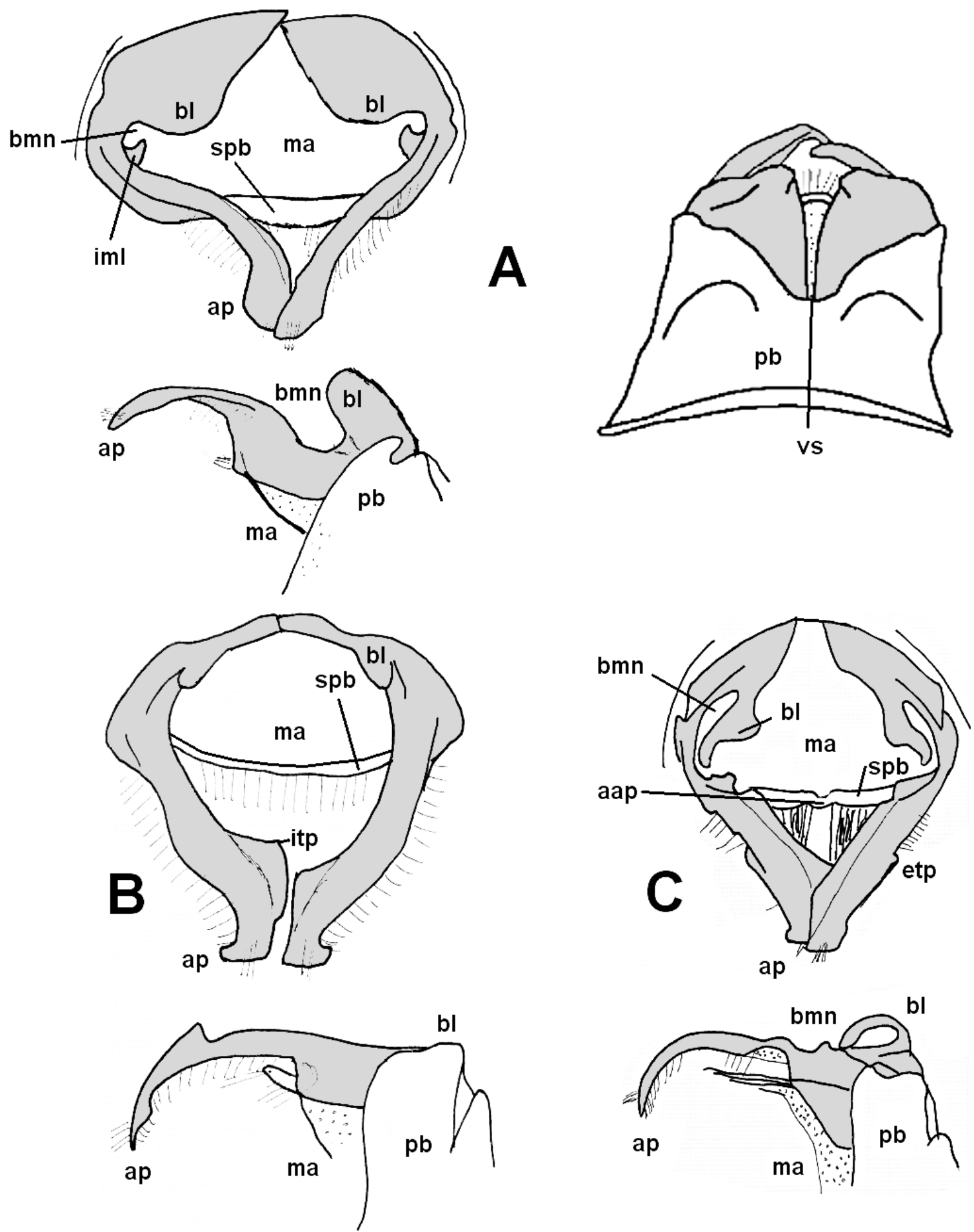

Fig. 3. Different shapes of aedeagus. A. Hybovalgus fraternus Moser, 1904. B. H. thibetanus (Nonfried, 1891). C. H. tonkinensis Moser, 1904. Proposed nomenclature of Hybovalgus aedeagus: aap = anterior apex of phallobase; ap = apex of parameres; $\mathrm{bl}=$ basal lobe; $\mathrm{bmn}=$ baso-medial notch; etp = sub-apical external tooth of parameres; iml = internal medial lobe; itp = sub-apical internal tooth of parameres; $\mathrm{ma}=$ membrane of aedeagus; $\mathrm{pb}=$ phallobase; $\mathrm{spb}=$ sclerotized upper anterior part of phallobase; vs $=$ V-shaped ventro-apically membranous region of aedeagus. Drawings: grey parts: parameres; white parts: phallobase. 


\section{Distribution}

Hybovalgus species are mostly distributed in south-central continental China, with most species extending to northern Laos, northern Vietnam, Hainan Island (5-6 species) and Taiwan. In Taiwan there are six species: Hybovalgus kamiyai (Sawada, 1941); H. major Sawada, 1939; H. matsudai Miyake, 1985; H. obsoletosquamosus Miyake, 1985; H. takasagoensis (Sawada, 1941) and H. thoracicus Moser 1911. These six Taiwanese species are considered endemic, but their relationships with continental Hybovalgus must still be analyzed.

Figure 4 shows the approximate distribution of Hybovalgus species. In the west, the genus inhabits Yunnan and Sichuan (there are no records so far for Myanmar). In the east some species reach Shandong, Jangsu and Zhejiang. In the north there are extensions into the southestern part of Palaearctic China (sensu Chen et al. 2008). We found no records of Hybovalgus from Henan and Anhui provinces or Chongqing Municipality, but this may be due to a lack of collecting.

\section{Summary of Chinese species distribution}

Hybovalgus bioculatus Kolbe, 1904: Laos, Vietnam, China (Hainan, Guangxi).

Hybovalgus calvus sp. nov.: Vietnam, China (Hainan).

Hybovalgus fraternus Moser, 1915: Vietnam, Laos, China (Fujian, Zhejiang, Sichuan, Guangxi, Jangxi,

Hunan, Guizhou).

Hybovalgus fulvosquamosus Moser, 1904: Laos, Vietnam, China (Hainan, Hunan, Guangdong).

Hybovalgus jordansi (Endrödi, 1952): China (Fujian).

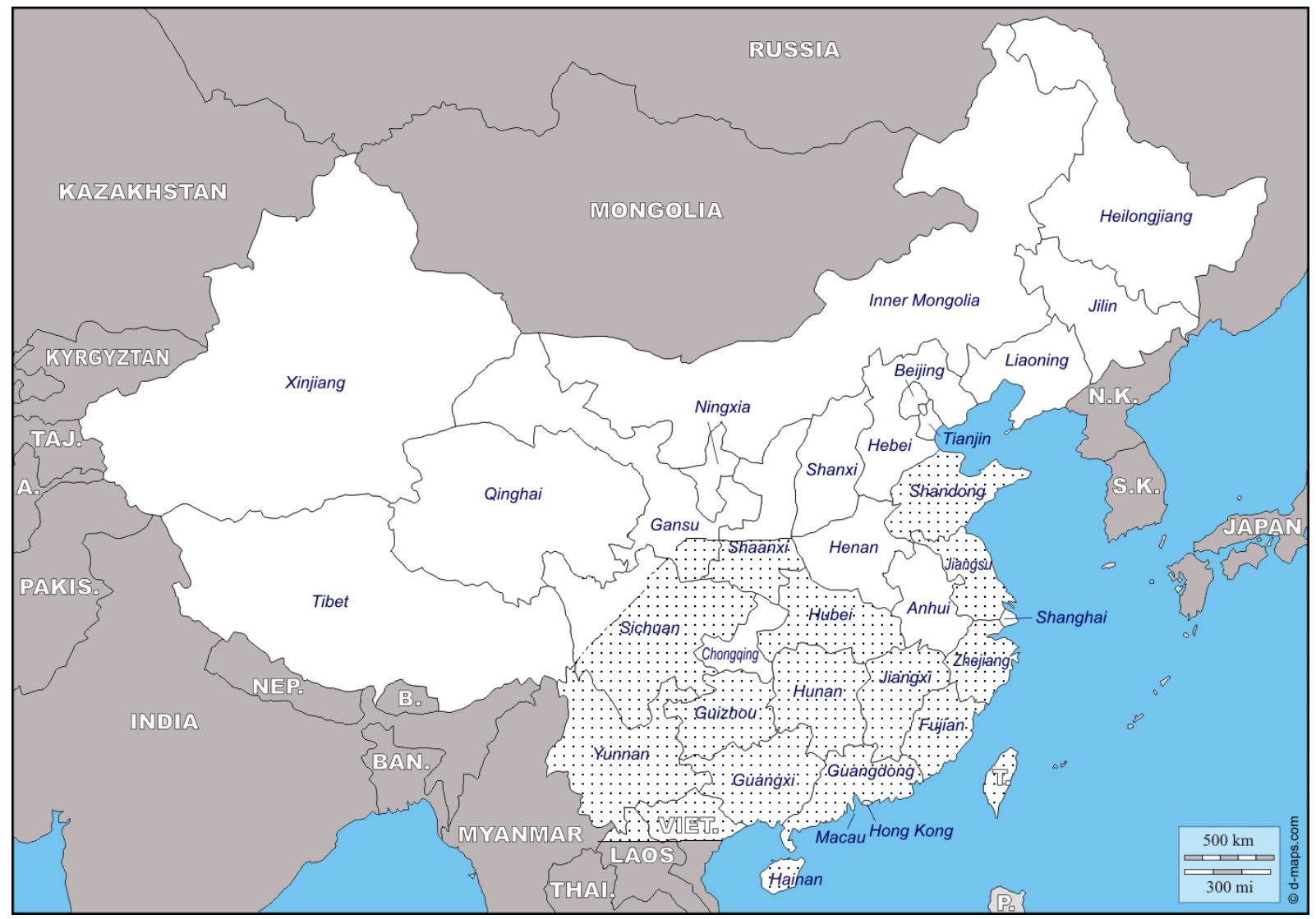

Fig. 4. Dotted area: approximate distribution of Hybovalgus. Original map from http://www.d-maps. com/pays.php?num_pay=77\&lang=it. 
Hybovalgus sexdentatus Arrow, 1944: Vietnam, Laos, China (Guangxi, Yunnan, Sichuan, Hainan, Shandong?).

Hybovalgus thibetanus (Nonfried,1891): China (Yunnan, Sichuan, Jangsu, Shaanxi, Jiangxi, Hubei, Gansu, Zhejiang).

Hybovalgus tonkinensis Moser, 1904: Vietnam, China (Fujian, Zhejiang, Jiangxi, Guangxi, Hunan, Guizhou, Hainan, Gansu, Sichuan).

Hybovalgus bioculatus Kolbe, 1904

Fig. 5

Hybovalgus bioculatus Kolbe, 1904: 56.

Hybovalgus bioculatus - Schenkling 1922: 51. - Ma 1995: 196, fig. 168, misidentification, it is Hybovalgus thibetanus.

\section{Material examined}

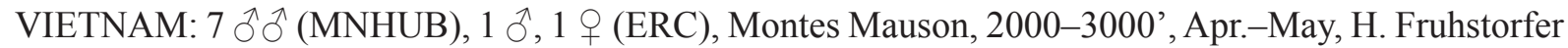
leg. (same locality and data of type series but these specimens are not labelled as such); $1 \hat{\partial}$, Vinh Phuc

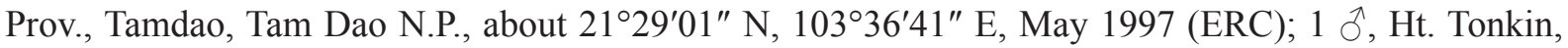

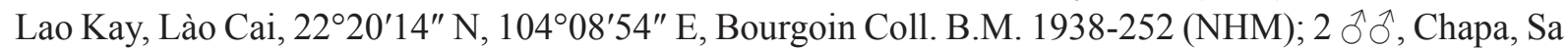

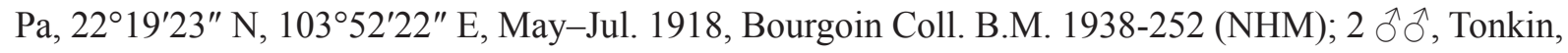
Chapa, 1 Jun. 1916, R.Vitalis de Salvaza leg., Bourgoin Coll. B.M. 1938-252 (NHM).

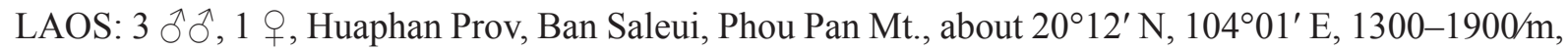
11 Apr.-15 May 2012, C.C. Holzschuh leg. (ZFMK); 1 ô, Huaphan Prov., Mt. Phu Phan, 2060 m, Apr.May 2012, local collectors (ERC).

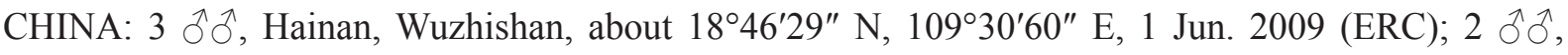

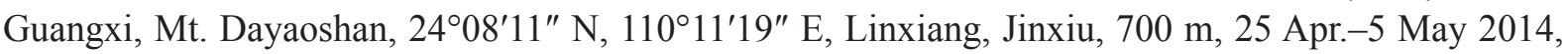
Huang Yuanyong and Li Dong leg. (ERC); 1 ふै, Guangxi, Mt. Dayaoshan, Pingzhao, Jinxiu, 1200 m, 15-25 May 2014, Zhao Jinsheng leg. (ERC).

\section{Remarks}

Kolbe (1904: 57) wrote that the locality where Fruhstorfer collected the type series was at 2-3000 m, but this is incorrect, as the original labels bears the mention " $2-3000$ " " (' = feet). In fact, the highest point of Montes Mauson is actually $1541 \mathrm{~m}$ (5249'). Many, or all of the specimens of H. bioculatus preserved at MNHUB and ERC most probably belong to the H. bioculatus type series, but they were not labelled as such by Kolbe who wrote "Eine Anzahl Exemplare". Scanning the literature dealing with $H$. bioculatus, we concluded that the female of this species was never described and probably Kolbe himself failed to pair the two sexes. This is clear because one of the specimens (ERC) is a female (described below), and Kolbe wrote on one small label "keine Forceps" without recognizing it as female.

Description of a female from Montes Mauson (ERC; type locality of the species)

MEASUREMENTs. Length $8.0 \mathrm{~mm}$; width $5.1 \mathrm{~mm}$. Body colour mostly castaneous.

HEAD. Black, slightly shiny, covered with large, round punctures each with a bristle-like, erect, testaceous scale. Clypeus black, with anterior margin castaneous, anterior margin sinuate, suctorial brush shorter than that of male. 
PRonotum. Black, nearly glabrous, trapezoidal, slightly crenate at sides, laterally depressed at center of lateral margins; anterior angle acute, posterior angle obtuse, apical margin rounded with a small ridge inclined at approximately $45^{\circ}$; posterior margin with central part deeply excavated as an enlarged "E" (Fig. 5F); carinae rounded, parallel, ending around middle of disk; central small carina not present; lateral carinae obsolete; with 2 testaceous, barely noticeable, central carina scale tufts; with 2 more or less noticeable, small, scales tufts at posterior angle.

SCUTELLUM. Black, long, apically rounded, nearly glabrous.

ELYTRA. Castaneous, slightly shiny, mostly glabrous, with shallow, black juxtascutellar depression, the anterior half of which is surrounded by a prominent ridge; humeral humbones prominent, with a small, testaceous scale tuft; anteapical umbones slightly prominent, with a prominent testaceous scale tuft directed posteriorly. Part of disk black, with thick, small, recumbent, barely noticeable scales.

Propygidium. Castaneous, slightly shiny, nearly glabrous, with scattered, small, recumbent black scales; posterior margin curved inward at middle, with 2 prominent, black propygidial scale tufts. Cones at posterior margin short and blunt.

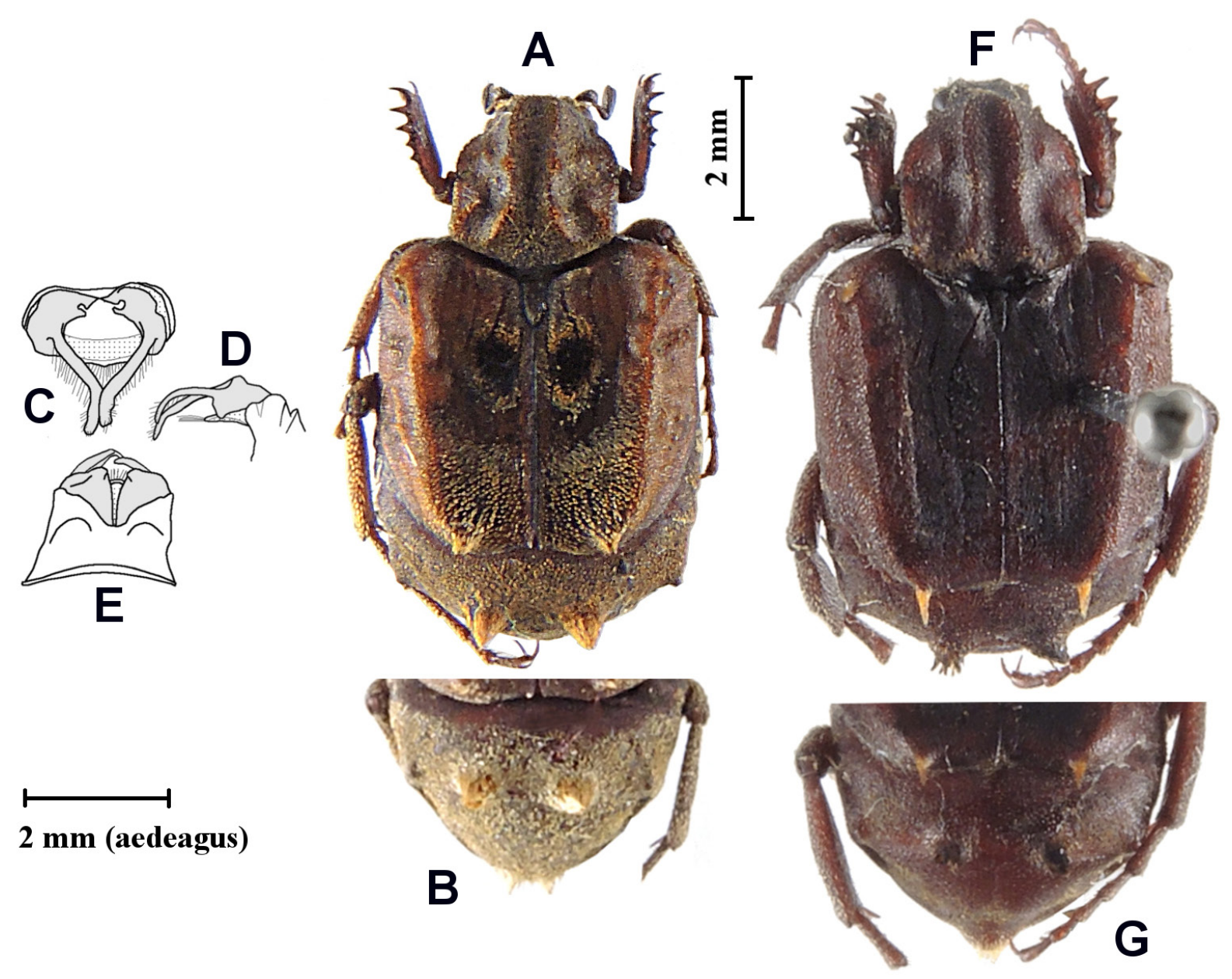

Fig. 5. Hybovalgus bioculatus Kolbe, 1904 (ERC). A-E. Ô. A. Habitus, dorsal view. B. Propygidium and pygidium. C-E. Aedeagus (grey: parameres; white: phallobase). C. Dorsal view. D. Lateral view. E. Posterior view. F-G. ․ . F. Habitus, dorsal view. G. Propygidium and pygidium. 
PYGIDIUM. Black, wider than long, slightly shiny, nearly glabrous, covered with scattered, small, recumbent, black scales; narrowing to apex, where there is a prominent rounded projection, showy in lateral view. Ventrally with a hollowed surface, glabrous and posteriourly semicircular. Apex with a prominent, testaceous scale tuft.

ProtiBia. Black, with 5 external teeth: 1-3 long, 4-5 smaller, all rounded at apex. Teeth 4-5 closer to one another than to $1-3$.

Meso- AND METAFEMUR. Castaneous with a small, testaceous scale tuft at centre of posterior margin.

Metatibia. Castaneous, centrally enlarged, without a tooth at center of posterior margin. First metatarsomere long, twice length of second.

AвDomen. Castaneous, covered with thick, recumbent, testaceous scales. Anal sternites longer than other visible sternites, with same scales but centrally glabrous.

\title{
Species variability
}

\section{Males}

Length 7.7-8.5 mm; width $4.5-5.1 \mathrm{~mm}$. The colour of the body is stable. Along posterior border of pygidium, in the places where Valgina often have scale tufts, $H$. bioculatus sometimes shows a glabrous surface, while in other specimens there are small, thick, erect scales whose colour varies from testaceous, to dirty testaceous to blackish. Lastly, in Chinese specimens the two posterior margin propygidial scale tufts and humeral humbone scale tufts are dirty testaceous instead of testaceous. Two of the three specimens from Guangxi have the basomedial notches of the parameres closed.

\section{Females}

The only two known females do not show any significant variation.

\section{Flight period}

The adults of this species were collected from mid-April to early June at an elevation of 700-1900 m.

\section{Distribution}

Hybovalgus bioculatus was described from northern Vietnam. New records reported here came from northern Laos and China (Hainan, Guangxi).

\author{
Hybovalgus calvus sp. nov. \\ urn:1sid:zoobank.org:act:2AE1E317-E510-4210-B843-973C1985BF3E
}

Fig. 6

\section{Diagnosis}

Hybovalgus calvus sp. nov. can easily be separated from all other Chinese Hybovalgus (except from H. jordansi) by the V-shaped protrusion at the posterior margin of the pronotum (Fig. 6A, D, J). The female pygidium apex lacks a protrusion. The parameres are different from those of $H$. bioculatus in the C-shaped apex (Fig. 6H). Females of Hybovalgus calvus sp. nov. can be distinguished from those of $H$. jordansi by the prominent testaceous scale tufts at the posterior margin of the pronotum; by the fringe of small, testaceous scales at the pygidial apex, instead of prominent, double-pointed testaceous scale tufts. The apex of the parameres of both species (Figs 6H, 8I) are inwardly C-shaped, but in $H$. jordansi they are thinner and tapered. 


\section{Etymology}

The name comes from the Latin word "calvus", meaning glabrous, as the integument of this species appears at first glance.

\section{Type material}

\section{Holotype}

VIETNAM: $\overbrace{}^{\Uparrow}$, Tonkin, Montes Mauson, Apr.-May, 2000-3000’, H. Fruhstorfer leg. (MNHUB).

\section{Paratypes}

VIETNAM: $1 \hat{\jmath}$ (ERC), 1 $\propto$ (MNHUB), same data as for HT.

CHINA: 1 ô, Hainan, Wuzhishan, 1 Jun. 2009 (ERC).

\section{Description}

\section{Holotype}

MEASUREMENTS. Length $8.2 \mathrm{~mm}$; width $5.1 \mathrm{~mm}$.

BoDy. Colour mostly black, with propygidium and pygidium dark castaneous.
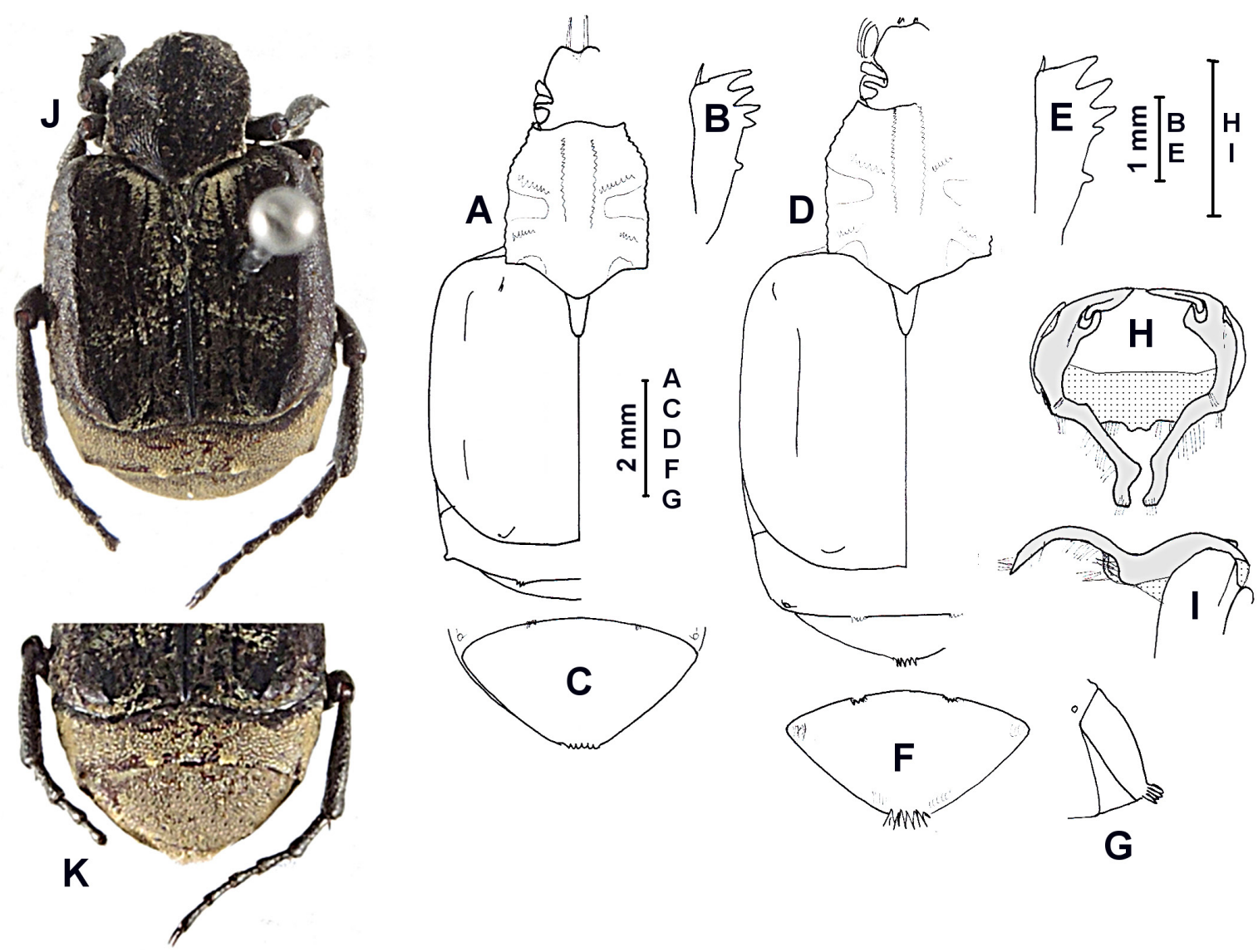

Fig. 6. Hybovalgus calvus sp. nov. A-C, H-I. HT $\partial^{\lambda}$ (MNHUB). A. Habitus, dorsal view. B. Protibia. C. Pygidium. H-I. Aedeagus (grey: parameres; white: phallobase). H. Dorsal view. I. Lateral view. D-G. PT $q$ (ERC). D. Habitus, dorsal view. E. Protibia. F. Pygidium, frontal view. G. Pygidium, lateral view. J-K. PT § (ERC). J. Habitus, dorsal view. K. Propygidium and pygidium. 
HEAD. Black, slightly shiny, covered with large round punctures; frons and vertex covered with small, recumbent, testaceous scales that do not form scale tufts. Clypeus black, anteriorly sinuate, suctorial brush long.

Pronotum. Black, nearly glabrous, trapezoidal, slightly crenate at sides, laterally depressed at center of lateral margins; anterior angle acute, posterior angle right-angled, with apex rounded; posterior margin with central part showily produced backwards, V-shaped, with apex rounded. Carinae rounded, parallel, ending around middle of disk; central small carina not present; lateral carinae not present; with 2 testaceous barely noticeable central carina scale tufts; without any other scale tufts. Covered with small, decumbent, scattered, testaceous scales.

Scutellum. Black, long, apically rounded, covered with small, decumbent, thick, testaceous scales.

ELYTRA. Black, slightly shiny, mostly glabrous, with barely noticeable juxtascutellar depression. Humbones slightly prominent, without scale tufts; anteo-central part of disk covered with hardly noticeable small, thick, decumbent black scales.

Propygidium. Dark castaneous, covered with thick, decumbent, small, coffee bean shaped, testaceous scales that form two small propygidium scale tufts; centre of posterior margin depressed; cones short and blunt.

Pygidium. Dark castaneous, wider than long, slightly depressed at sides in ventral half. Covered with thick, decumbent, small, coffee grain shaped, testaceous scales which form a fringe of long scales at apex. Apex rounded, without projection. Under apex, in ventral view, there is a hollowed, semicircular, glabrous, horizontal surface.

ProtiBia. Black, with 5 external teeth: 1-3, long, 4-5 smaller, all rounded at apex. Teeth 3-4 closer to one another than 1-3; tooth 5 rather spaced apart from 4 (Fig. 6B).

Meso- AND METAFEMUR. Black, with a fringe of small, testaceous scales at centre of posterior margin which do not form a small scale tuft.

MetaTiBIA. Black, centrally enlarged at posterior margin, without a tooth at centre. First metatarsomere long 1.8 times the length of second.

AbDomen. Dark castaneous, covered with thick, recumbent, testaceous scales, scattered at centre of 1-3 visible sternites. Anal sternites, with same scales but centrally glabrous.

Paratype $q$ (differences from HT)

MeAsurements. Length $9.5 \mathrm{~mm}$; width $5.7 \mathrm{~mm}$. Body dark castaneous.

The female is quite similar to the male, not showing great differences in the shape of the posterior margins of the pronotum or pygidium apex. The first is pointed at the apex, the latter is regularly rounded. The propygidium is much wider than long, shaped as in the male but with a small depression close to each superior corner.

\section{Type series variability}

Males: length $8.0-8.4 \mathrm{~mm}$; width $4.7-5.3 \mathrm{mmm}$. A PT $\overbrace{}^{\Uparrow}$ has the propygidium, pygidium and abdomen black. 


\section{Flight period}

The Vietnamese types were collected from May to early June at an elevation of 700-1500 m.

\section{Distribution}

Present in northern Vietnam and China (Hainan).

Hybovalgus fraternus Moser, 1915

Fig. 7

Hybovalgus fraternus Moser, 1915: 603.

Excisivalgus csikii Endrödi, 1952: 63, syn. nov.

Hybovalgus fraternus - Schenkling 1922: 51. — Krajčík 2011: 92, fig. 48.

Excisivalgus csikii - Krajčík 2011: 91.

\section{Type material}

Lectotype (here designated)

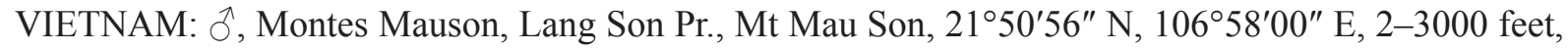
Apr--May, H. Fruhstorfer leg. (MNHUB).

Paralectotype (here designated)

VIETNAM: $1 \hat{\gamma}$, same data as the LT (MNHUB).

\section{Other type material examined}

Holotype of Excisivalgus csikii Endrödi, 1952

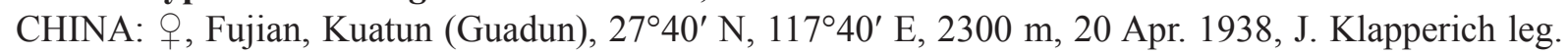
(ZFMK).

\section{Other material examined}

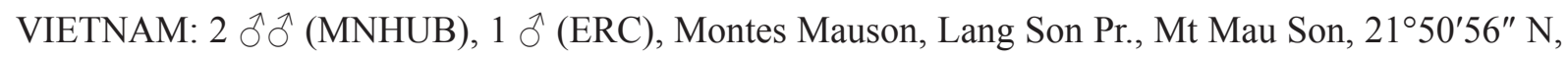
$106^{\circ} 58^{\prime} 00^{\prime \prime}$ E, 2-3000 feet, Apr.-May, H. Fruhstorfer leg.

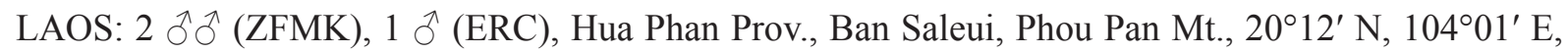

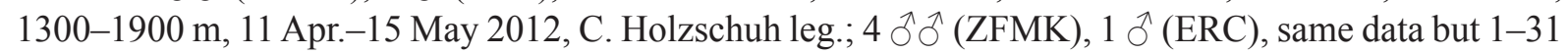
May 2011.

CHINA: $65 \widehat{\partial} \widehat{\jmath}$, Fujian, Kuatun (Guadun), $27^{\circ} 40^{\prime} \mathrm{N}, 117^{\circ} 40^{\prime} \mathrm{E}, 24-28$ Apr. 1946, Tschung-Seng leg.

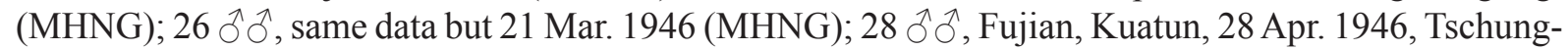

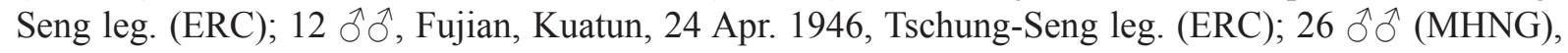

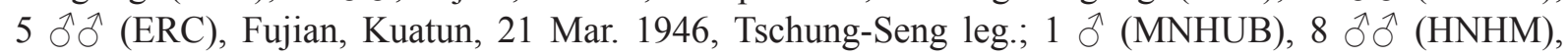

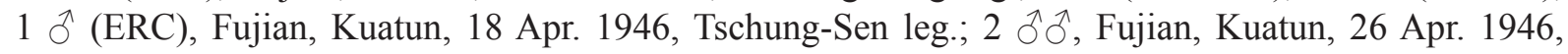

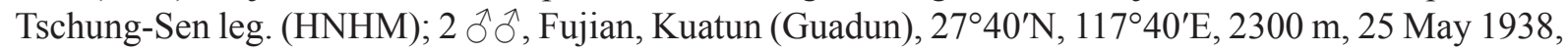
J. Klapperich leg. (HNHM); 1 §, same data but 6 Apr. 1938 (HNHM); 1 §, same data but 20 May 1938

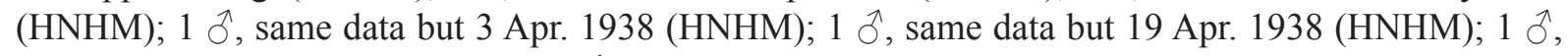

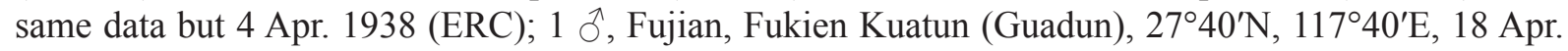

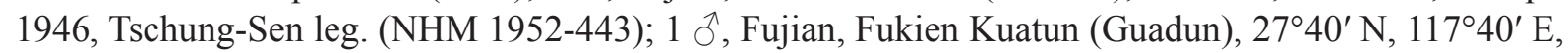
26 Apr. 1946, Tschung-Sen leg. (NHM 1952-443); $6 \curvearrowright ð$, Zhejiang, Changlongshan, Anji, 800-900 m,

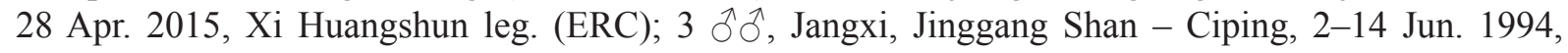

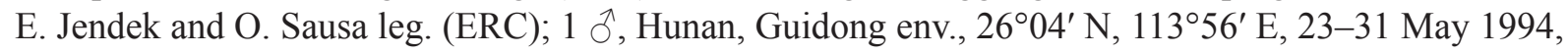


E. Jendek and O. Sausa leg. (ERC); 3 $\widehat{\partial}, 1$ क , Guizhou, $60 \mathrm{~km}$ North of Kaili, Shibing-Yuntai Shan, 21-26 May 1995, E. Jendek leg. (ERC); 6 ô ô, Guangxi, Mt. Dayaoshan, Linxiang, Jingxiu, 700 m, 25 Apr.-5 May 2014, Huang Yuanyong and Li Dong leg. (ERC); 1 ð̂, Guangxi, Mt. Dayaoshan, Pingban, Jingxiu, 1200 m, 5 May 2014, local collectors (ERC); 1 ô, Sichuan, Mt. Quingcheng Shan, 26 May 1990, Jima Nara leg. (ERC).

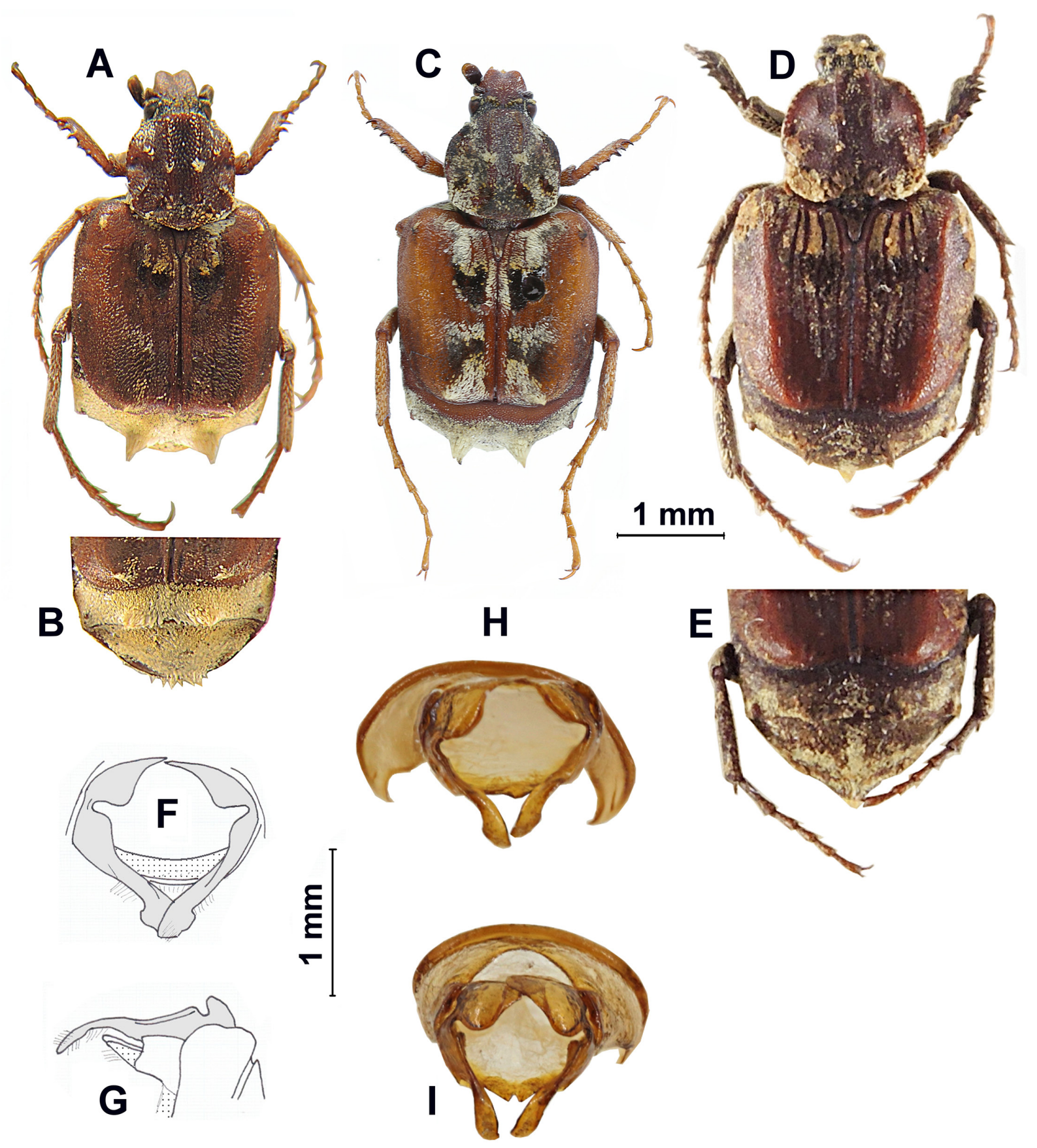

Fig. 7. A-C. Hybovalgus fraternus Moser, 1904. A-B. ô (ERC). A. Habitus, dorsal view. B. Propygidium

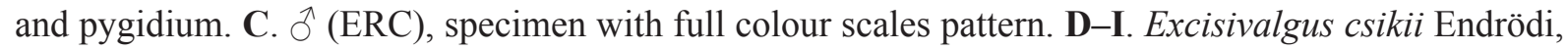
1952. D-E. HT, o (ZFMK). D. Habitus, dorsal view. E. propygidium and pygidium. F-G. LT, $ぇ$ (MNHUB). F. Aedeagus, dorsal view. G. Aedeagus, lateral view (grey: parameres; white: phallobase). H-I. $3 \widehat{\partial}$ (IZAS), aedeagus of some Chinese specimens. 


\section{Remarks}

The analysis of many males from northern Vietnam, northern Laos and China shows that, despite the great variability in paramere shape (particularly the size of the basomedial notch and basal lobe, but many males show intermediate dimensions), there is otherwise little morphological variation within males: the black posterior corner and carina posterior scale tufts are sometimes reduced or barely noticeable. The size of males varies from $5.4 \mathrm{~mm}$ (width $3.5 \mathrm{~mm}$ ) to $6.8 \mathrm{~mm}$ (width $4.3 \mathrm{~mm}$ ). Sometimes the elytra scale pattern is reduced (Fig. 7A), but it is unclear if this is due to wear or real pattern variability.

One female (ERC) from Guizhou was collected at the same locality and date as three males and its general aspect and all the morphology allows it to be assigned to H. fraternus. This female can be separated from the male by the posterior margin of the pronotum slightly excavated as an enlarged ' $\mathrm{C}$ ', the apex of the pygidium prominently pointed.

Many males of H. fraternus were collected by J. Klapperich in April 1938 near Kuatun (Guadun, Fujian, $29^{\circ} 37^{\prime} 46^{\prime \prime} \mathrm{N}, 117^{\circ} 40^{\prime} 01^{\prime \prime} \mathrm{E}$ ). At least one of these males (HNHM) was collected on the same day (20 April) and at the same locality as the type series of Excisivalgus csikii Endrödi, 1952. The morphology of the HT of E. klapperichi csikii being identical to the Guizhou $H$. fraternus female, we concluded that Excisivalgus csikii Endrödi, 1952 is a junior synonym (ㅇ) of Hybovalgus fraternus Moser, 1915.

The two females are larger than the males. The female from Fujian (HT of E. csikii) is $7.3 \mathrm{~mm}$ long and $4.2 \mathrm{~mm}$ wide, while the one from Guizhou (ERC) is $6.9 \mathrm{~mm}$ long and $4.5 \mathrm{~mm}$ wide.

\section{Flight period}

Adults of $H$. fraternus were collected from the first days of April to the beginning of June, at an elevation of $700-2300 \mathrm{~m}$.

\section{Distribution}

This species was described from northern Vietnam. Records from Laos and China (Fujian, Zhejiang, Sichuan, Guangxi, Hunan, Guizhou, and Jiangxi) are new.

\section{Hybovalgus fulvosquamosus Moser, 1904}

Fig. $8 \mathrm{~K}-\mathrm{N}$

Hybovalgus fulvosquamosus Moser, 1904: 272.

Hybovalgus fulvosquamosus - Schenkling 1922: 51.

\section{Type material}

Lectotype (here designated)

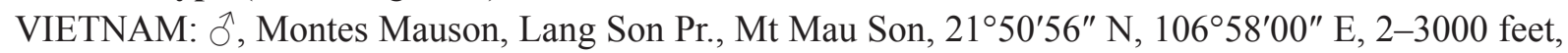
Apr.-May, H. Fruhstorfer leg. (MNHUB).

Paralectotypes (here designated)

VIETNAM: $4 \widehat{\partial} \widehat{\partial}$, same data as LT (MNHUB).

\section{Other material examined}

VIETNAM: 1 đ̊, Tonkin, Tam Dao, May 1997 (ERC); 1 ô, same data but May 1993 (ERC). 


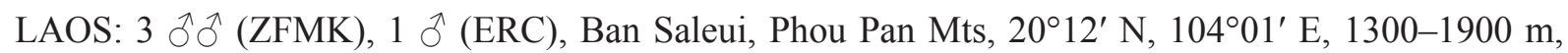
7 Apr.-25 May 2010, C. Holzschuh leg.; 1 đે, same data but 11 Apr.-15 May 2012 (ZFMK).

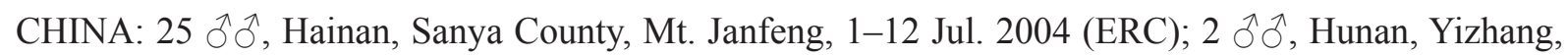
Mangshan, 1270-1340 m, 14-17 Jul. 2008, Zhu Xiaoyu and Yang Zhuo leg., IOZ(E) 1945060/63

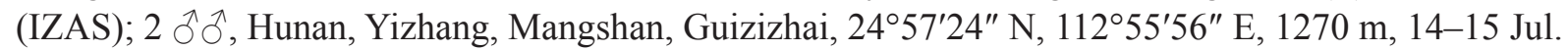

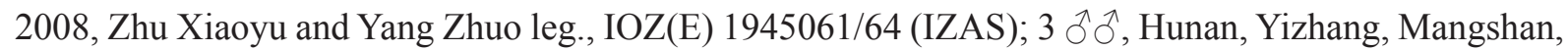

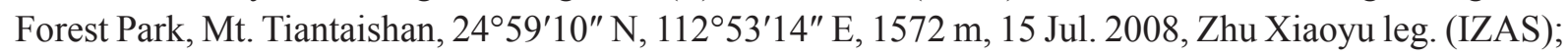
1 ô, border of Hunan, Mangshan and Guangdong Nanling, 17 Jul. 2008, Liang Hongbin leg., IOZ(E) 1945062 (IZAS); 1 đ, Guangdong, Shixing, Chebaling Nature Reserve, Xianrendong,(244ㄴ $16^{\prime \prime}$ N, $114^{\circ} 13^{\prime} 6^{\prime \prime}$ E, 508 m, 23 Jul. 2008, Zhu Xiaoyu leg. (IZAS).

\section{Remarks}

The female is unknown.

\section{Species variability}

Species of variable size: length $6.7-8.3 \mathrm{~mm}$; width $3.9-4.5 \mathrm{~mm}$.

The specimens from Hainan have the pronotum, elytron and legs darker, sometimes nearly black. One specimen from Laos has the scales on the propygidium and pygidium darker. In general all scale tufts are small to barely noticeable.

\section{Flight period}

Hybovalgus fulvosquamosus adults appear in Vietnam and Laos between April and June. Instead, all Chinese specimens were collected in July. Collected between 500 and $1500 \mathrm{~m}$.

\section{Distribution}

Described from northern Vietnam. New records are from Laos and China (Guangdong, Hunan and Hainan).

Hybovalgus jordansi (Endrödi, 1952), comb. nov.

Fig. $8 \mathrm{H}-\mathrm{J}$

Dasyvalgus jordansi Endrödi, 1952: 65.

Dasyvalgus jordansi - Krajč́́k 2011 (gives incorrect year of description: Endrödi, 1953): 89.

\section{Type material}

\section{Paratypes}

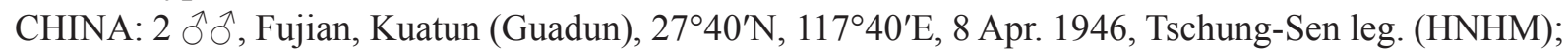

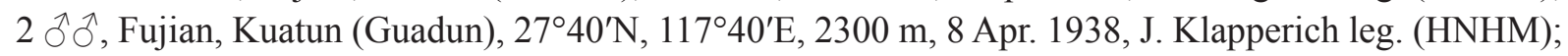

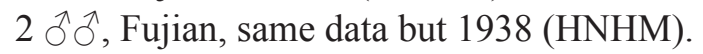

\section{Other material examined}

CHINA: $3 \partial^{\lambda} \partial^{\lambda}$, Fujian, Kuatun (Guadun), $27^{\circ} 40^{\prime} \mathrm{N}, 117^{\circ} 40^{\prime} \mathrm{E}, 21$ Mar. 1946, Tschung-Sen leg. (ERC);

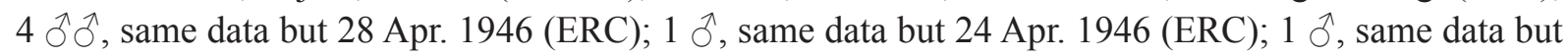
29 Apr. 1946 (ERC). 


\section{Remarks}

This species was described by Endrödi (1952) as Dasyvalgus jordansi Endrödi, 1952. Having its parameres clearly of the same shape as in Hybovalgus (Fig. 8I-J), we include this species in the latter genus (new combination).

The female is unknown.

\section{Species variability}

Hybovalgus jordansi shows little morphological variation, but varies in size (length 5.6-6.5 mm; width $3.3-3.9 \mathrm{~mm}$ ). In some specimens the posterior half of the lateral margin of the pronotum narrows in a straight line from the middle to the posterior corner; in other specimens it narrows in the same way, but noticeably arched inwards. The latter is a morphological character used by Miyake (1985) as a main character in his key to Taiwanese Hybovalgus species, but it seems like an unstable character to separate the continental species of the genus.

\section{Flight period}

Adults of H. jordansi were collected from the end of March to the end of April.

\section{Distribution}

This species seems to be endemic to the northern mountains of Fujian (China).

\section{Hybovalgus sexdentatus Arrow, 1944}

Fig. $8 \mathrm{~A}-\mathrm{F}$

Hybovalgus sexdentatus Arrow, 1944: 238.

Hybovalgus sexdentatus - Ma 1995: 197, fig. 169.

\section{Type material}

\section{Lectotype}

LAOS: đ̊, Ban Naban, 15 Mar. 1915, R. Vitalis de Salvaza leg. (NHM).

\section{Paralectotypes}

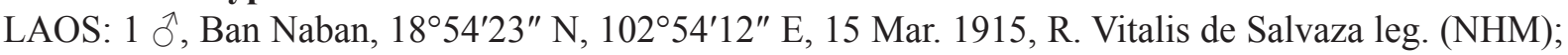

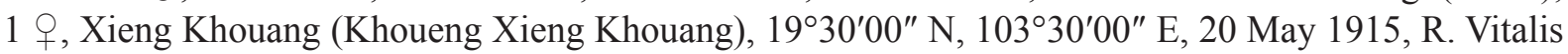
de Salvaza leg. (NHM).

\section{Other material examined}

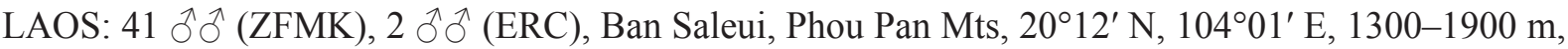

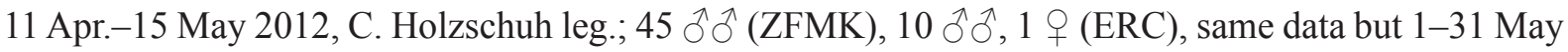
2001; 1 đ̃, Ban Saleui, Phu Pan Mts, Apr.-May 2012, local collectors (ERC).

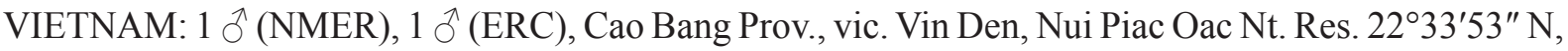
105'52'53" E, 900-1300 m, 6-10 May 2012, A. Weigel leg.

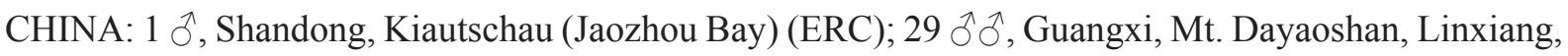
Jinxiu, 700 m, 25 Apr.-5 May 2014, HuangYuanyong \& Lidong leg. (ERC); 1 ऽ, Guangxi, same data but

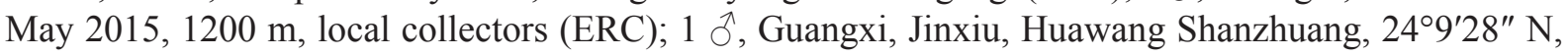
1107'12" E, 600 m, 20 May 1999, Yang Xingke leg., IOZ(E) 902246 (IZAS); 1 ô, Guangxi, Daxin 

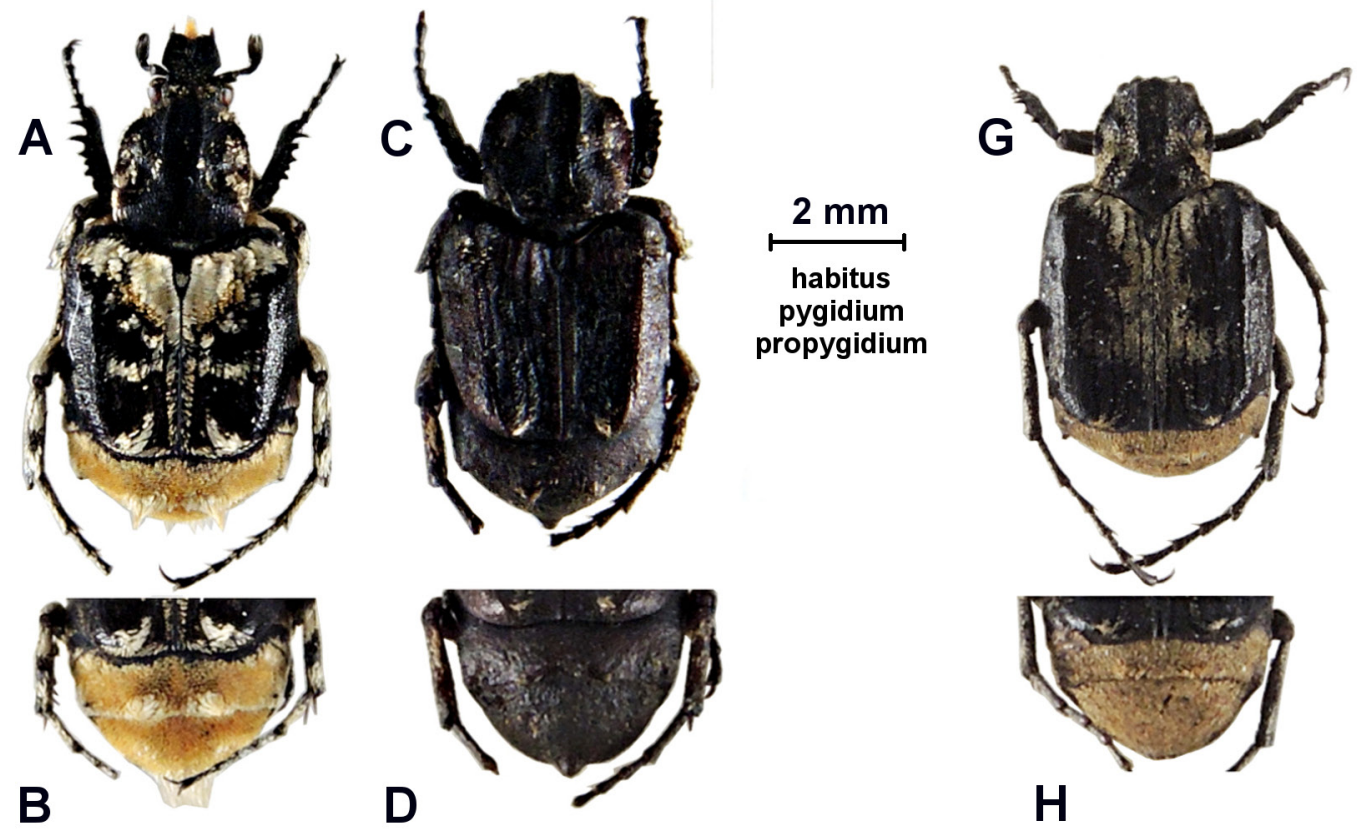

D
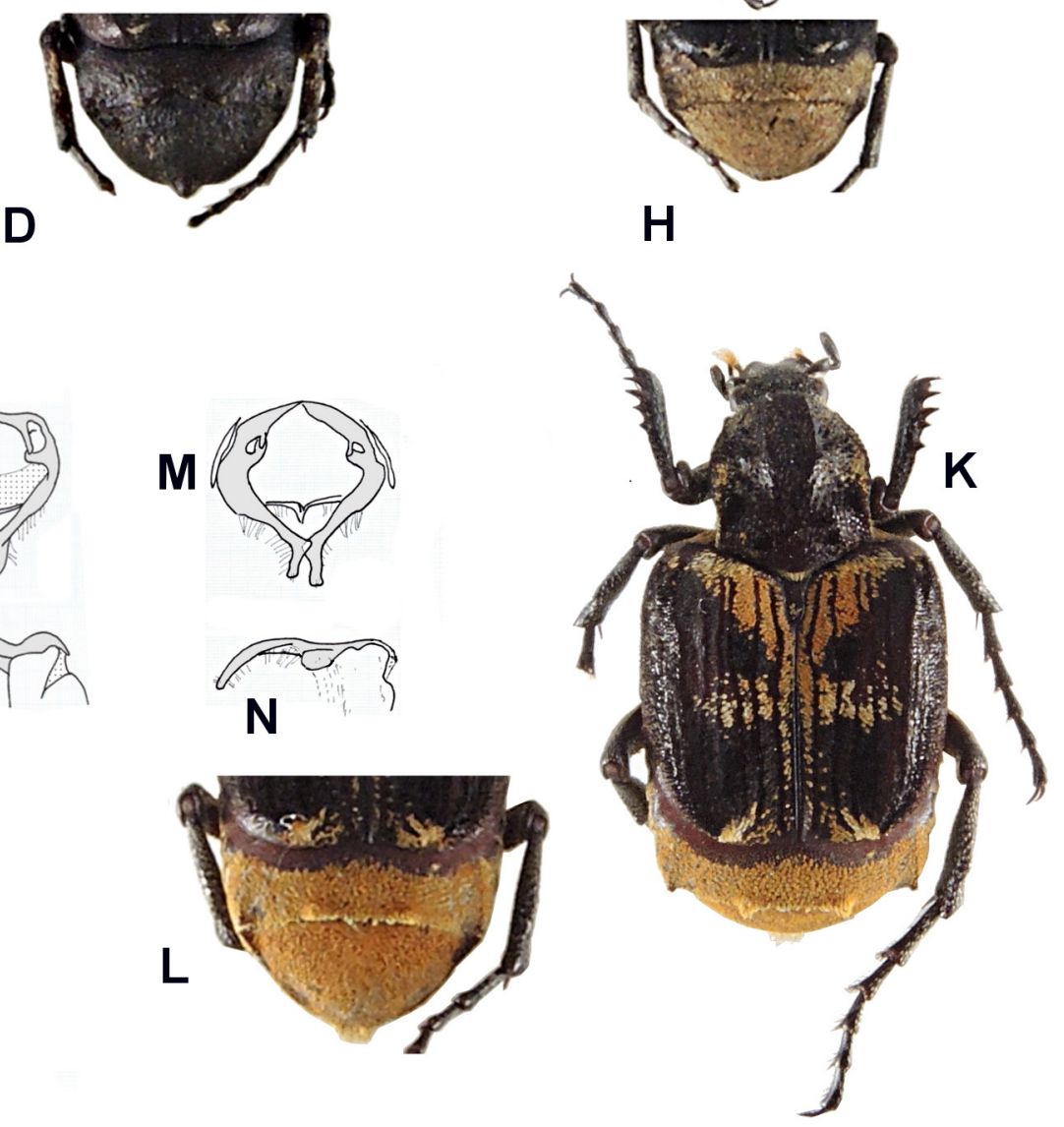

Fig. 8. A-F. Hybovalgus sexdentatus Arrow, 1944. A-B. O (ERC). A. Habitus, dorsal view. B. Propygidium and pygidium. C-D. $\odot$ (ERC). C. Habitus, dorsal view. D. Propygidium and pygidium. E-F. PLT, $\widehat{\jmath}(\mathrm{NHM})$. E. Aedeagus, dorsal view. F. Aedeagus, lateral view. G-J. Hybovalgus jordansi (Endrödi, 1952). G-H. ô (ERC). G. Habitus, dorsal view. H. Propygidiun and pygidium. I-J. PT, $\widehat{\jmath}$ (HNHM). I. Aedeagus, dorsal view. J. Aedeagus, lateral view. K-N. Hybovalgus fulvosquamosus Moser, 1904. K-L. đ̊ (ERC). K. Habitus, dorsal view. L. Propygidiun and pygidium. M-N. LT, ð (MNHUB). M. Aedeagus, dorsal view. N. Aedeagus, lateral view. Drawings: grey parts: parameres; white parts: phallobase. 
Xialei Town, 2254'49" N, 10645'50" E, 680 m, 31 Mar. 1998, Li Wenzhu leg., IOZ(E) 902246 (IZAS);

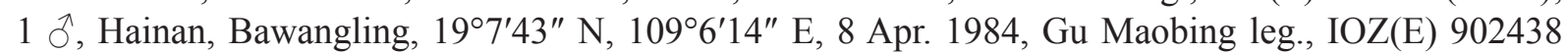

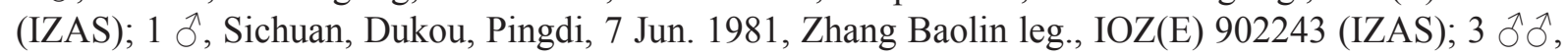

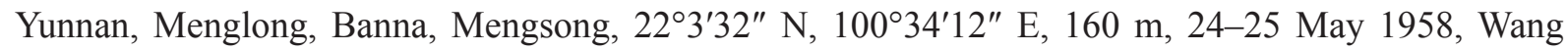
Shuyong, Zheng Leyi and Pu Fuj leg., IOZ(E) 902255-57 (IZAS).

\section{Remarks}

According to Arrow (1944), the type series comprised three specimens, all from Laos. In his work Arrow seemed not to realize that one of the types was a female, as he described only the male. Paulian (1961), applying the International Code of Zoological Nomenclature, amended the name of this species from $H$ sex-dentatus (Arrow, 1944) to H. sexdentatus, but Bacchus (1974) erroneously misspelled the name of the species again and designated the type series of three specimens, LT, one PLT male and one PLT female, but did not describe the latter, which remained undescribed until now. In this work we restate that the hyphen must be eliminated as the correct name is $H$. sexdentatus, and give the differences between sexes.

Identification of female (from the $q$ at ERC)

The size of females is more or less the same as that of the biggest males and the shape of the posterior margin of the pronotum is simply rounded, without protrusions or excavations. The protibia external margin has six teeth, as in the male.

At first glance the female can be distinguished by the pygidium shape: its apex is protruding and pointed (Fig. 8D).

\section{Species variability}

The length of males varies from 4.7 to $7.5 \mathrm{~mm}$; the width from 3.0 to $4.1 \mathrm{~mm}$. The only female known so far is $7.4 \mathrm{~mm}$ long and $3.5 \mathrm{~mm}$ wide.

The study of 148 specimens leads to the conclusion that the species is morphologically slightly variable. In males the only variations observed are:

- Propygidial scales and scale tufts testaceous or whitish.

- The scales on the elytron are sometimes black and testaceous, sometimes black and whitish.

- The legs are black or castaneous.

- On occasion, protibia teeth 3-4 and 5-6 are closer to one another than to 1-3.

\section{Flight period}

Specimens were collected between mid-March and the first week of June at an elevation comprised between 160 and $1900 \mathrm{~m}$.

\section{Distribution}

Hybovalgus sexdentatus was described from Laos and recorded by Ma (1995) from Yunnan. New records reported here are from northern Vietnam and China (Guangxi, Hainan, Sichuan). One specimen is labelled as from Shandong (Jaozhou Bay), but this record is doutbful without further finds.

\section{Hybovalgus thibetanus (Nonfried, 1891)}

Fig. 9

New synonyms: Hybovalgus laticollis Arrow, 1944; Hybobalgus yunnanus Moser, 1906; Valgus savioi Pic, 1928; Dasyvalgus pubicollis Pic, 1928, Hybovalgus versicolor Moser, 1908. 
Valgus thibetanus Nonfried, 1891: 372.

Hybovalgus yunnanus Moser, 1906: 403. syn. nov.

Hybovalgus versicolor Moser, 1908: 259. syn. nov.

Dasyvalgus pubicollis Pic, 1928b: 4. syn. nov.

Valgus savioi Pic, 1928a: 7. syn. nov.

Hybovalgus laticollis Arrow, 1944: 238. syn. nov.

Dasyvalgus thibetanus Krajčík, 2011: 92, fig. 46.

Valgus thibetanus - Schenkling 1922: 43.

Hybovalgus yunnanus - Schenkling 1922: 51. — Krajčík 2011: 93.

Hybovalgus versicolor - Schenkling 1922: 51. — Krajčík 2011: 93.

Dasyvalgus pubicollis - Krajčík 2011: 90.

Valgus savioi - Krajčík 2011: 96.

Hybovalgus laticollis - Krajč́́k 2011: 92.

non Hybovalgus bioculatus - Ma 1995: 196, fig. 168. Misidentification.

\section{Type material}

Note: all types here designated have a red type label. Alla data reported are copied from specimen labels.

Lectotype (here designated)

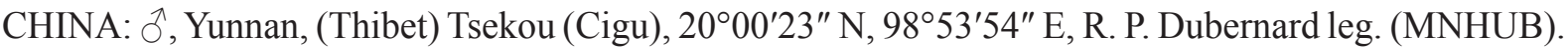

Paralectotype (here designated)

CHINA: 1 ${ }^{\lambda}$, same data as LT (MNHUB).

Other type material examined

Lectotype of Hybovalgus laticollis Arrow, 1944

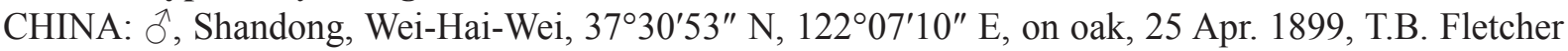
leg. (NHM).

Syntype of Hybovalgus yunnanus Moser, 1906

CHINA: $\hat{\jmath}$, Yunnan (SDEI).

Type of Valgus savioi Pic, 1928

CHINA: ô, China, 23 Apr. 1918 (MNHN).

Lectoype of Dasyvalgus pubicollis Pic, 1928

CHINA: $\widehat{\jmath}$, Thibet (MNHN).

Lectotype of Hybovalgus versicolor Moser, 1908 (here designated)

CHINA: + , Yunnan (MNHUB).

\section{Other material examined}

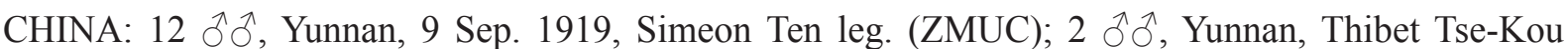

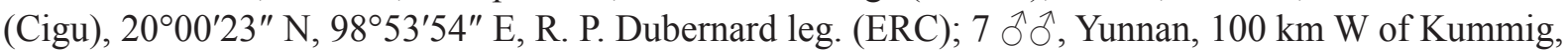

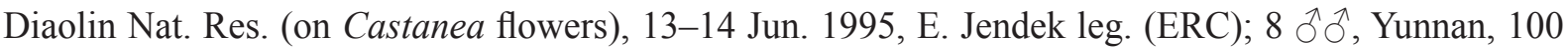
km W of Kummig, Diaolin Nat. Res., 22 May-2 Jun. 1993, E. Jendek and O. Sausa leg. (ERC); 3 §̄ô, Yunnan (ERC); $1 \mathrm{O}^{\top}$, Yunnan, Tse Kou, $28^{\circ} 02^{\prime} \mathrm{N}, 98^{\circ} 54^{\prime} \mathrm{E}, 2000$ m, 7-8 Jun. 2006, Jifi Klir leg. (ERC); 1 , Shaanxi, Foping env., 120 km SW of Xian, 7 Jun. 1992, M. Bok leg. (SNMS); 1 , Shaanxi, Chin- 
Lins Mts (Quing Ling Mts), Apr.-May 1904 (USNM); 1 क, Shaanxi, Chin-Lins Mts (Quing Ling Mts)

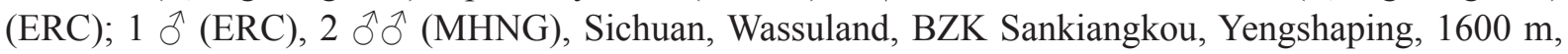

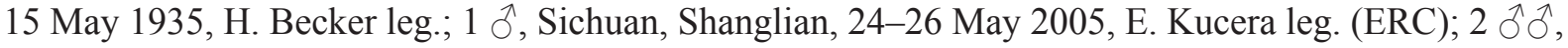
Sichuan, same data but 24-29 May 2002 (ERC); 1 \%, Sichuan, Luding Co, Moxi env., 22 May-10 Jun. 1993, Beneš leg. (ERC); 1 đ (MNHUB), 1 đ̄ (ERC), Jangxi, Kiukiang (Jujiang), Jul. 1887, A.E. Pratt leg.; 1 ô, Hubei, Ichang (Ychang), 6-8000 ft, May (MNHUB); 1 đે, Gansu, South Gansu, Venxian env., 18-25 Jun. 1995, Beneš leg. (ERC); 1 §, Gansu, Kansou mer., Hoei Sein (ERC); 7 $\widehat{\jmath}, 5$ 우

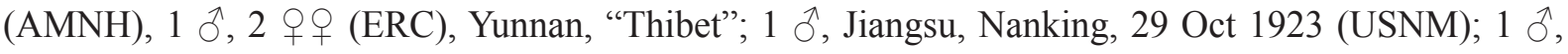

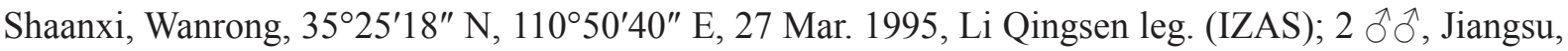

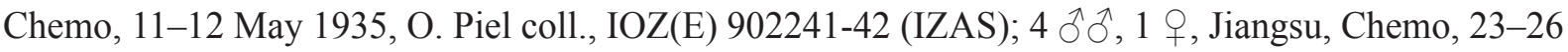
Apr. 1918, IOZ(E) 902238-40, IOZ(E) 902473 (IZAS); 1 §ै, Zhejiang, Mokanshan, IOZ(E) 902251 (IZAS); 1 đે, Zhejiang, Suichang suburb, 24 Apr. 1988, Dong Sansong leg., IOZ(E) 902440 (IZAS); 1 đ̃, Zhejiang, Chusan, 23 Apr. 1935, IOZ(E) 902253 (IZAS); 1 ㅇ, Hubei, Xingshan, Longmen River,

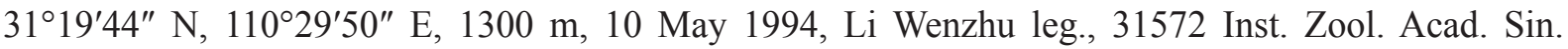

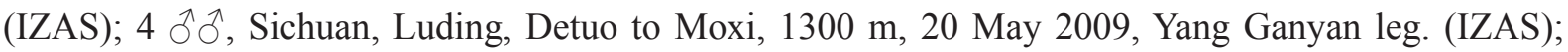

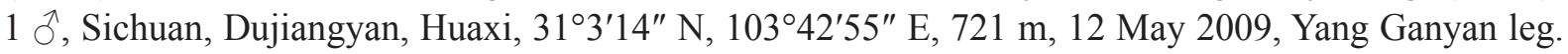

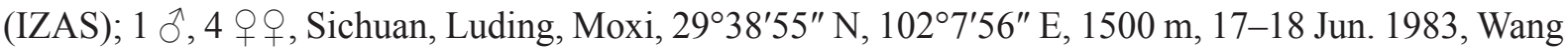
Shuyong and Chen Yuanqing leg., IOZ(E) 902156-57/235 (IZAS); 1 ㅇ, Sichuan, Wanxian, Wang'erbao, 3040'7" N, 10845'30" E, 1200 m, 28 May 1994, Zhang Youwei leg., 36965 Inst. Zool. Acad. Sin.,

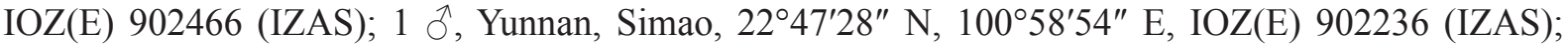
$1 \delta^{\top}$ (H. bioculatus sensu Ma Wenzhen, 1992) Yunnan, Gongshan County, Bingzhongluo, 28 $0^{\prime} 55^{\prime \prime} \mathrm{N}$, 98³7'58" E, 1790 m, Sino-Ameica Exped., 6 Jul. 2000, Liang H.B. N28.01 E98.61 (IZAS); 1 q,

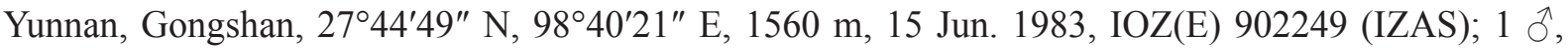

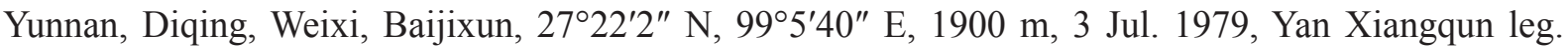

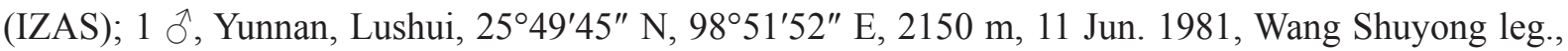

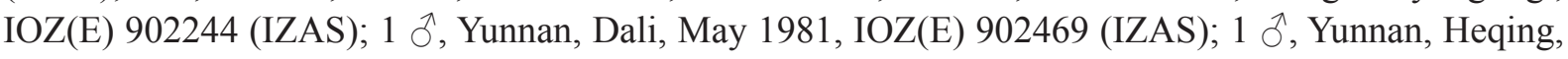

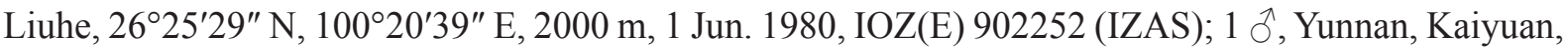
Mazheshao, 234' $38^{\prime \prime} \mathrm{N}, 103^{\circ} 25^{\prime} 32^{\prime \prime} \mathrm{E}, 1800 \mathrm{~m}, 26$ Apr. 1970, Wang Zhengjun etc. leg., IOZ(E) 902250 (IZAS); 1 đ̊, Yunnan, Fugong, 1196 m, 18 May 1983, IOZ(E) 902468 (IZAS).

\section{Remarks}

In a long period of time when valgine specimens rarely reached European museums from China, specimens of $H$. thibetanus were described several times under different names. Study of the types of several Chinese species, i.e., Hybovalgus yunnanus Moser, 1906; Valgus pubicollis Pic, 1928; Dasyvalgus savioi Pic, 1928 and Hybovalgus laticollis Arrow, 1944, showed us that these species are morphologically close to one another and their aedeagi are nearly identical. Even Pic described this species twice under two different names in the same year (Pic 1928a, 1928b). Finally, when Arrow (1944) described H. laticollis, due to World War II, types deposited in other European museums were inaccessible for study and he had to work on the basis of descriptions only, and it is known that Pic's descriptions were too concise.

Until now the female of $H$. thibetanus was unknown. Krajčík (2011), listing H. versicolor Moser, 1908 within the Chinese Valginae (sensu Krikken 1984), doubtfully proposed that this species is the female of, and thus a junior synonym of, $H$. thibetanus. The study of the LT (Moser 1908 did not specify how many specimens he had for study) of $H$. versicolor and morphological comparison with $H$. thibetanus confirm that the two specimens are male and female of the same species, whose correct name is $H$. thibetanus (new junior synonym). The synonymy is reinforced by the study of eleven other females collected in the same locality and at the same day as the males (see list of material examined). 

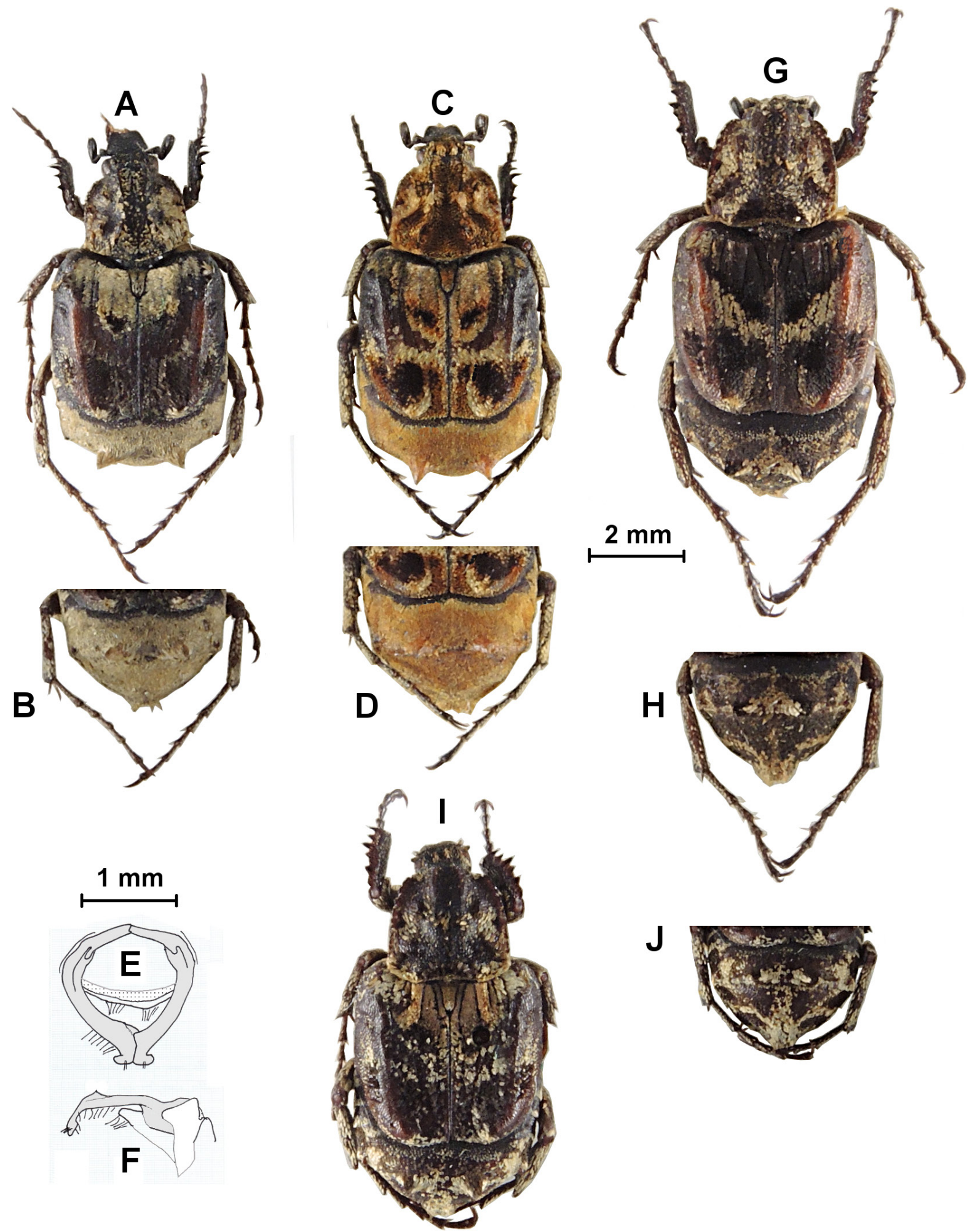

Fig. 9. Hybovalgus thibetanus (Nonfried, 1891). A-B. ô from Sichuan (ERC). A. Habitus, dorsal view. B. Propygidium and pygidium. C-D. ô from Yunnan (ERC). C. Habitus, dorsal view. D. Propygidium and pygidium. E-F. LT, $\widehat{\jmath}$ (MNHUB). E. Aedeagus, dorsal view. F. Aedeagus, lateral view (grey: parameres; white: phallobase). G-H. o from Sichuan (ERC). G. Habitus dorsal view. H. Propygidium and pygidium. I-J. + from Shaanxi (ERC). I. Habitus, dorsal view. J. Propygidium and pygidium. 


\section{Species variability}

\section{Males}

In most specimens the legs are black, but in a few they are castaneous. The same is true for the propygidium and pygidium. The scales on the propygidium and pygidium vary in colour, from light testaceous to dark testaceous (see Fig. 9A-D). Sometimes the last visible sternites and the anal sternite are glabrous instead of covered with thick scales. The size of males is variable: length from 5.7 to $7.6 \mathrm{~mm}$; width from 3.5 to $4.2 \mathrm{~mm}$.

\section{Females}

The colour of the integuments and scales varies in the same way as in males. The same with size: length from to 5.8 to $8.3 \mathrm{~mm}$; width from 3.3 to $4.0 \mathrm{~mm}$.

\section{Flight period}

Specimes were collected between the end of March and early June. Some specimens are labelled as having been collected in September and October (see list of studied material), but these records must be confirmed by other finds. Specimens have been collected from 700 to $2000 \mathrm{~m}$.

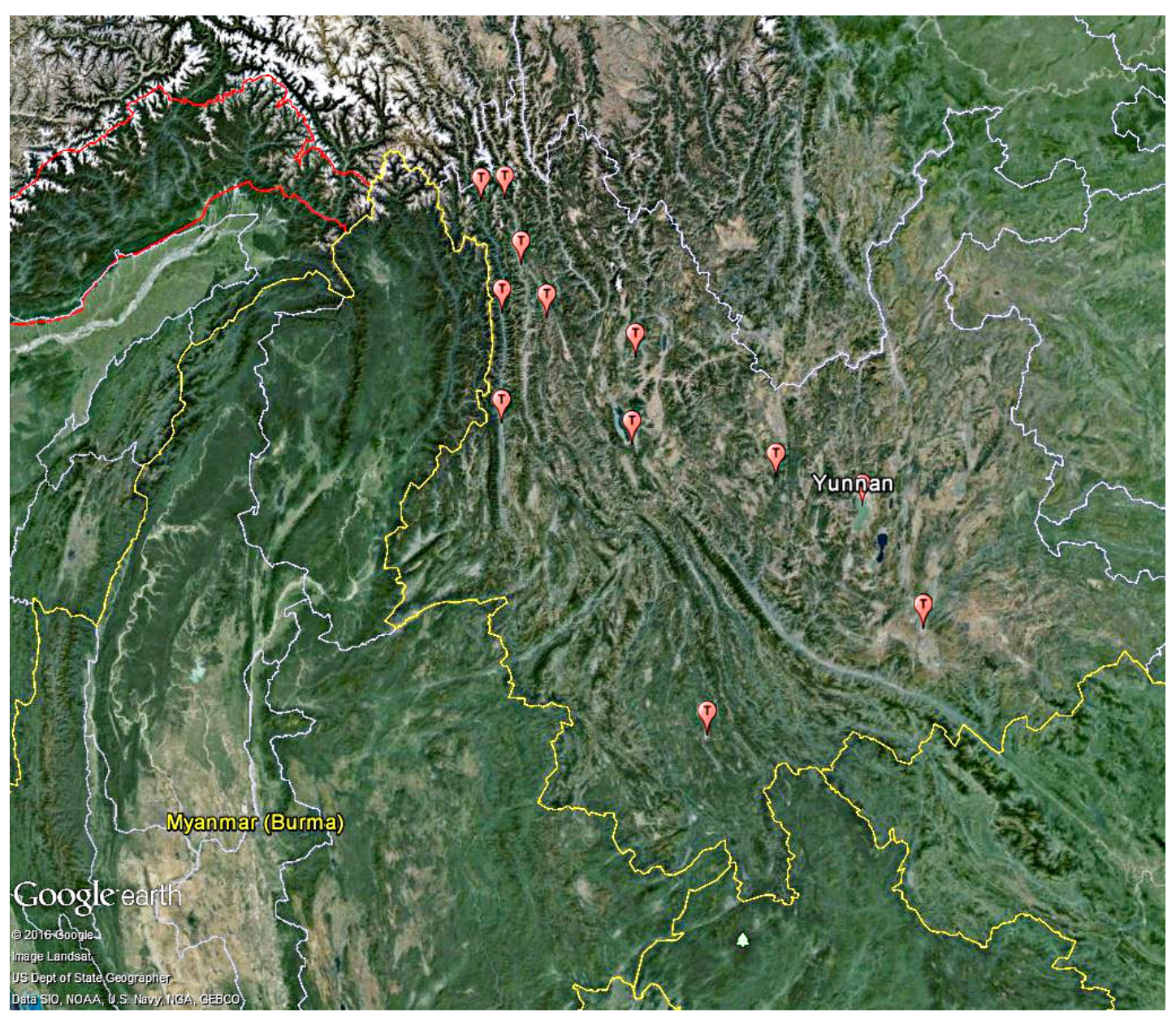

Fig. 10. Localities in Yunnan where specimens of Hybovalgus thibetanus (Nonfried, 1891) were collected. Base Map from Google Earth. 


\section{Distribution}

Hybovalgus thibetanus is endemic to continental China and inhabits most of the central provinces: Yunnan, Sichuan, Jiangsu, Shaanxi, Jiangxi, Hubei, Gansu and Zhejiang. The absence from the other central provinces of China (Guizhou, Hunan, Anhui and Henan) is probably due to a lack of collecting. Hybovalgus thibetanus seems to be absent from the southern Chinese Provinces; we have no records from Guangxi, Guangdong, Hainan or Fujian.

The name of this species, "thibetanus", is from ancient collecting when the northernmost parts of Yunnan were considered to be part of Tibet. To date, there are no specimens of this species known to us collected in Myanmar, Arunachal Pradesh or the southern Xizang valleys, but the presence of $H$. thibetanus there is possible (see Fig. 10, which shows the distribution of H. thibetanus in Yunnan's valleys close to Myanmar's borders).

\section{Hybovalgus tonkinensis Moser, 1904}

Fig. 11

Hybovalgus tonkinensis Moser, 1904: 272.

Excisivalgus klapperichi Endrödi, 1952: 63 syn. nov.

Hybovalgus tonkinensis - Schenkling 1922: 51. — Krajčík 2011: 93, fig. 47.

Excisivalgus klapperichi - Krajčík 2011: 91, fig. 54.

non Hybovalgus thoracius Ma 1995: 196. Misidentification.

\section{Type material}

Lectotype (here designated)

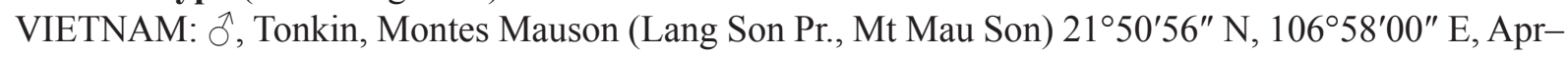
May, 2000 - 3000', H. Fruhstorfer leg. (MNHUB).

Paralectotype (here designated)

VIETNAM: $1 \hat{\jmath}$, same data as LT (MNHUB).

\section{Other type material examined}

Excisivalgus klapperichi Endrödi, 1952

\section{Holotype}

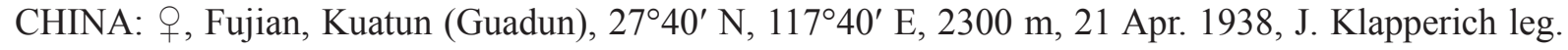
(ZFMK).

\section{Paratypes}

CHINA: 1 , same data as HT but 24 Mar. 1938 (HNHM); 1 , same data but 8 Apr. 1938 (ZFMK); 4 우, same data but 28 Mar. 1938 (ZFMK); 1 , same data but 28 Apr. 1938 (ZFMK); 1 , same data but 24 Apr. 1938 (ZFMK); 1 ㅇ, Fujian, Kuatun, (Guadun), 2740’ N, 11740’ E, 28 Apr. 1946, Tschung Sen leg. (SNMS).

\section{Other material examined}

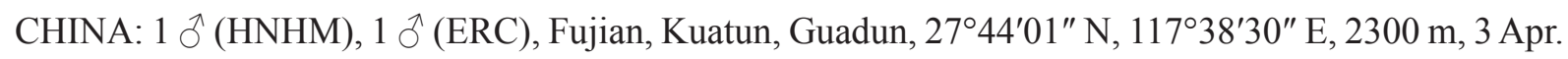

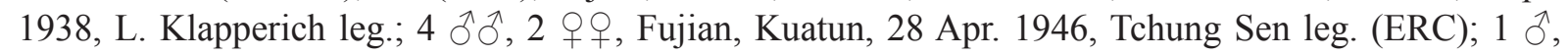
Fujian, Kuatun, 21 Mar. 1946, Tchung Sen leg. (ERC); 2 đ̊̄, Fujian, Kuatun, 24 Apr. 1946, Tchung Sen leg. (ERC); 1 ठ̊, Fujian, Kuatun, 22 Apr. 1946, Tchung Sen leg. (MNHUB); 1 O, Fujian, same data but 
18 Apr. 1946 (HNHM); 1 đ̊, Fujian, Kuatun, 27.40 N, 117.40 O, 2300 m, 20 Apr. 1938, L. Klapperich leg. (HNHM); 2 §ぇ, Fujian, same data but 8 Apr. 1938 (HNHM); 1 §, Fujian, same data but 5 Apr. 1938

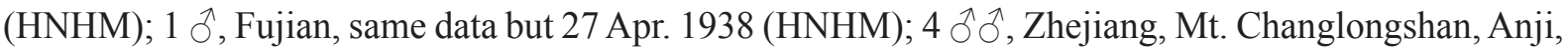

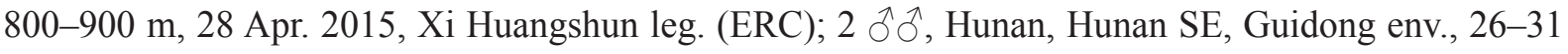
May 1994, E. Jendek and O. Sausa leg. (ERC); 6 $\widehat{\partial}$, Guizhou, 20 km NW of Jangkow, Fanjing Shan, 27 May-3 Jun. 1995, E. Jendek leg. (ERC); 1 ○, Hainan, Wuzhishan, 1 Jun. 2009 (ERC); 4 $\precsim$, China, Jangxi, Jinggang Shan, Ciping, 2-14 Jun. 1994, E. Jendek and O. Sousa leg. (ERC); 1 Oे, Guangxi, Mt. Dayaoshan, Jinxin, Pingzhao, 1200 m, May 2015 (ERC); 1 ઈิ, Guangxi, same data but 15-25 May 2014,

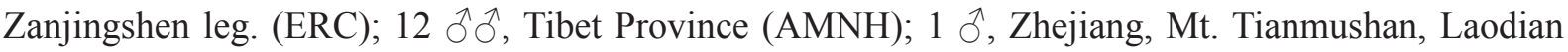
30²0'448" N, 119²6'44" E, 9 May 1998, Yu Zhiyong leg. (IZAS); 1 ô, Zhejiang, Tiemushan, 13 May 1937, O. Piel Coll., IOZ(E) 902263 (IZAS); 1 đૈ, Zhejiang, Tiemushan, 10 May 1937, O. Piel Coll., IOZ(E) 902263 (IZAS); 1 ð̊, Zhejiang, E. Tiemushan, 30¹9'2" N, 119³1'60" E, 12 Jun. 1936, IOZ(E) 902269 (IZAS); 1 ठૈ, 1 \&, Fujian, Mt. Wuyishan, 22 Apr. 1982, Zhang Baolin leg., IOZ(E)

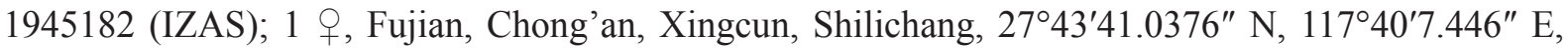
840 m, 25 May 1960, Jiang Shengqiao leg., IOZ(E) 902233 (IZAS); 1 +, Fujian, Chongan, Xingcun,

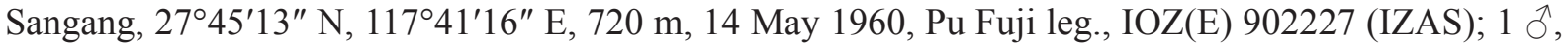
Fujian, Jiangyang, road from Huangkeng to Guilin, 290-320 m, 12 Apr. 1960, Jiang Shengqiao leg.,

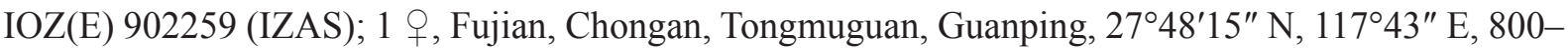
900 m, 6 Jun. 1960, Jiang Shengqiao leg., IOZ(E) 902228 (IZAS); 1 + , Fujian, Chongan, Tongmuguan, Guanping $27^{\circ} 48^{\prime} 15^{\prime \prime}$ N, 117 43" E, 800-900 m, 6 Jun. 1960, Jiang Shengqiao leg., IOZ(E) 902229 (IZAS); 1 , Fujian, Jianyang, road from Huangkeng to Guilin, 270 m, 11 Apr. 1960, Ma Chenglin leg., IOZ(E) 902231 (IZAS); 1 ð’, Fujian, Jianyang, Huangkeng to Guilin, 290-320 m, 14 Apr. 1960, Jiang Shengqiao leg., IOZ(E) 902260 (IZAS); 1 ○े, Fujian, Jianyang, road from Huangkeng to Guilin, 290-320 m, 12 Apr. 1960, Jiang Shengqiao leg., IOZ(E) 902258 (IZAS); 1 q, Fujian, Jianyang,

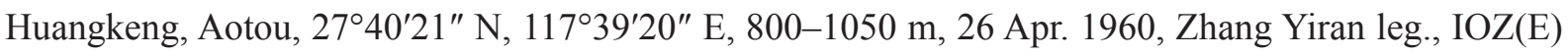

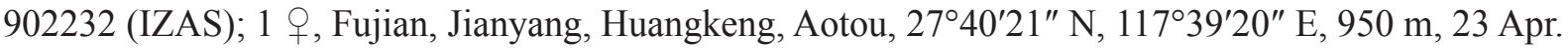
1960, Zuoyong leg., IOZ(E) 902264 (IZAS); 1 ô, Fujian, Chongan, Xingcun, Qiliqiao, 2744'4" N, $117^{\circ} 40^{\prime} 31^{\prime \prime}$ E, 840 m, 1 Jun. 1960, Zuo Yong leg., IOZ(E) 902261 (IZAS); 1 +, Guizhou, Suiyang,

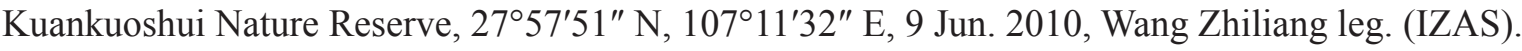

VIETNAM: 1 ð, Tamdao, 17-21 May 1990, P. Pacholatko leg. (ERC); 1 ○े, Tamdao, 12-24 May 1990, P. Pacholatko leg. (ERC).

\section{Remarks}

Endrödi (1952) described Excisivalgus klapperichi Endrödi, 1952 on the basis of 57 females from Kuatun (Guadun, Fujian) as a new species belonging to the new genus Excisivalgus Endrödi, 1952. He did not try to pair this species (and a second one, Excisivalgus csikii Endrödi, 1952; see section Remarks above under $\mathrm{H}$. fraternus) to the many males of Hybovalgus collected from the same locality and named the new genus after the wide excision of the posterior margin of the pronotum. Actually, we found that E. klapperichi is the female of $H$. tonkinensis, as evidenced by the capture of both sexes in the same place and time. An additional proof is the presence in the IZAS collection of a pair in copula (see the material examined list and Fig. 2).

\section{Identification of female}

The female (formerly Excisivalgus klapperichi Endrödi, 1952) can be easily separated from males by the wide and deep excision of the pronotal posterior margin; by the modified apex of the pygidium and by the black propygidial scale tufts. Furthermore, the ventral side of females is glabrous (Fig. 11H). 


\section{Species variability}

\section{Male}

Males are variable, even in size (length 6.9-9.2 mm, width 3.8-5.2 mm). The pygidium of males has a double pointed testaceous scale tuft at the apex, rarely reduced to a fringe of scales. The small scales that cover the propygidium and pygidium vary from testaceous to whitish. The abdomen varies from nearly glabrous to covered with whitish scales at the sides. The posterior half of the pronotal lateral margin varies from slightly indented to slightly arched outwardly. The interteguments of some specimens from Zhejiang are castaneous instead of black, with the pronotum darkened at the anterior and posterior margins; one specimen from the same Chinese province shows black pronotal posterior margin scale tufts (as, in general, is the case in females) instead of testaceous. The parameres do not vary much in shape.

\section{Female}

Females show variable scale patterns on the elytra (Fig. 11E-I). Furthermore, the colour of the small scales covering the propygidium and pygidium varies from dirty testaceous (sometimes somewhat orange) to black. Less variable in size than males, generally constantly greater, but not attaining the size of the bigger males (female length 8.2-8.6 mm, width 4.9-5.2 $\mathrm{mm}$ ).
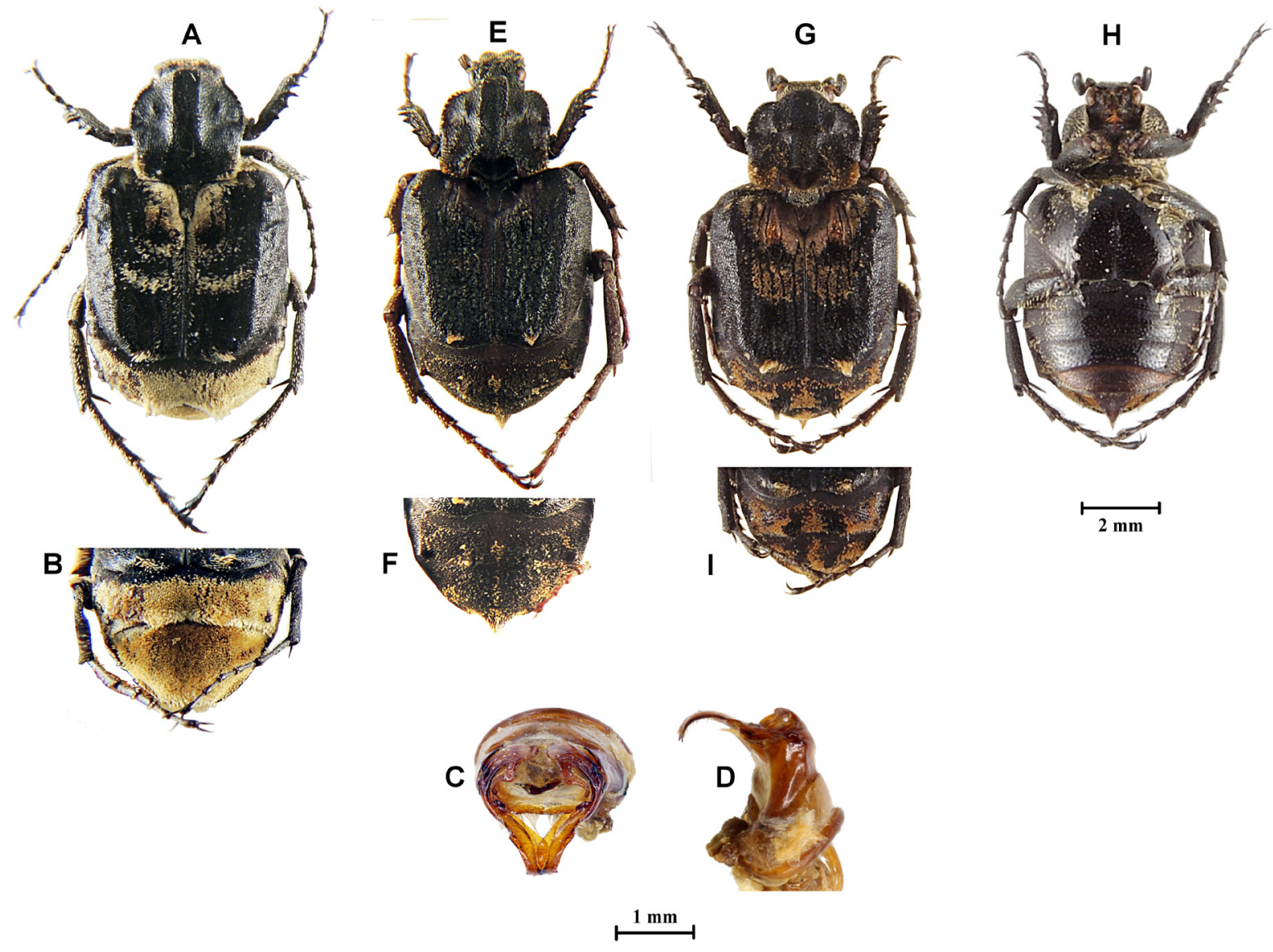

Fig. 11. A-D. Hybovalgus tonkinensis Moser, 1904. A-B. §ో from Fujian (ERC). A. Habitus, dorsal view. B. Propygidium and pygidium. C-D. PLT, §̂ (MNHUB). C. Aedeagus, dorsal view. D. Aedeagus, lateral view. E-I. Excisivalgus klapperichi Endrödi, 1952. E-F. HT, o (ZFMK). E. Habitus, dorsal view. F. Propygidium and pygidium. G-I. PT, $q$ (ZFMK). G. Habitus, dorsal view. H. Habitus, ventral view. I. Propygidium and pygidium. 


\section{Flight period}

Adults were captured from early April to mid-June, at elevations from 300 to $1600 \mathrm{~m}$.

\section{Distribution}

Described from northern Vietnam. New records are from China (Fujian, Zhejiang, Jangxi, Guangxi, Hunan, Guizhou, Hainan, Gansu and Sichuan). New finds are necessary to better define the distribution of H. tonkinensis in Sichuan and Gansu. The absence of reports from Yunnan is probably due to a lack of research.

\section{Discussion}

The purpose of this paper is to clarify and redescribe the species composition of Chinese Hybovalgus, assign to it several species previously belonging to other Valgina genera, establish several new synonyms, and provide a more detailed distribution of species. Lastly, one new species from Hainan and northern Vietnam, Hybovalgus calvus sp. nov., is described.

One of the main problems in identifying specimens for study is that many (old or recently collected) are discoloured due to a buildup of grease. In such cases, determining the colours or presence/absence of scales is critical and any misinterpretation could lead to an incorrect identification. This is why in this work the pattern of scales on the body was not highlighted.

In general, the form of the parameres for determination is reliable, with the exception of $H$. fraternus that shows broad morphological variation.

The determination of Hybovalgus females (females of six of eight Chinese Hybovalgus are known) is now easier thanks to several distinct morphological characters here presented.

\section{Acknowledgments and credits}

Sha Li's research was supported by the National Science Fund for Fostering Talents in Basic Research (Special Subjects in Animal Taxonomy, NSFC-J1210002) and the Research Equipment Development Project of the Chinese Academy of Sciences (YZ201509). Many thanks to Brett Ratcliff who gave us much helpful advice to improve the text and contents.

\section{References}

Arrow G.J. 1944. The beetles of the Lamellicorn subfamily Valginae, with a synopsis of the genera and descriptions of some new species. Transactions of the Royal Entomological Society 94 (2): 225-246. https://doi.org/10.1111/j.1365-2311.1944.tb01218.x

Bacchus M.E. 1974. A catalogue of the type-specimens of the Cetoniinae (Coleoptera: Scarabaeidae) described by G.J. Arrow. Bulletin of the British Museum (Natural History), Entomology 31 (2): 25-44.

Bouchard P., Bousquet Y., Alonso-Zarazaga M.A., Lawrence J.F., Lyal C.H.C., Newton A.F., Reid C.A.M., Schmitt M., Slipinski S.A. \& Smith A.B.T. 2011. Family-group names in Coleoptera (Insecta). ZooKeys 88: 1-972. https://doi.org/10.3897/zookeys.88.807

Chen L., Song Y. \& Xu S. 2008. The boundary of Paleartic and Oriental realms in western China. Progress in Natural Science 18 (7): 833-841. https://doi.org/10.1016/j.pnsc.2008.02.004

Endrödi S. 1952. Neue und bekannte Hopliinen und Valginen aus der Fukien-Ausbeute des Herrn J. Klapperich. Folia Entomologica Hungarica (series nova) 5 (2): 41-71. 
Jameson M.L. \& Swoboda K.A. 2005. Synopsis of the scarab beetle tribe Valgini (Coleoptera: Scarabaeidae: Cetoniinae) in the New World. Annals of the Entomological Society of America 98 (5): 658-672. https://doi.org/10.1603/0013-8746(2005)098[0658:SOSBTV]2.0.CO;2

Kolbe H.J. 1897. Beiträge zur Kenntniss der melitophilen Lamellicornier (Coleoptera). VIII. Die Afrikanischen Genera und Spezies der Valgiden. Entomologische Zeitung 58: 184-215.

Kolbe H.J. 1904. Gattungen und Arten der Valgiden von Sumatra und Borneo. Stettiner Entomologische Zeitung 65: 3-57.

Krajčík M. 2011. Illustrated Catalogue of Cetoniinae, Trichiinae and Valginae of China (Coleoptera: Cetoniidae). Animma. X, Supplement 1/2011. Plzen.

Krikken J. 1978. Valgine beetles: a preliminary review of the genera, with descriptions of two novelties. Zoologische Mededelingen 53 (15): 153-164.

Krikken J. 1984. A new key to the suprageneric taxa in the beetle family Cetoniidae, with annotated lists of the known genera. Zoologische Verhandelingen 210: 1-75.

Ma W.Z. 1995. Economic insect fauna of China (Coleoptera: Cetoniidae: Trichiidae and Valginae). Fauna Sinica 46: 168-202.

Miyake Y. 1985. A revision of the subfamily Valginae from Taiwan. The Society of Lamellicornia 1: $1-14$.

Moser J. 1904. Neue Valgiden-Arten. Berliner Entomologische Zeitschrift 49: 266-273.

Moser J. 1906. Beitrag zur Kenntnis der Cetoniden. Annales de la Société Entomologique de Belgique 50: 395-404.

Moser J. 1908. Beitrag zur Kenntnis der Cetoniden. Annales de la Société Entomologique de Belgique 52: 252-261.

Moser J. 1911. Beitrag zur Kenntnis der Cetoniden (IX). Annales de la Société Entomologique de Belgique 55: 119-129.

Moser J. 1915. Neue Melolonthiden und Cetoniden (Col.). Deutsche Entomologische Zeitschrift 1915 (6): 579-605. https://doi.org/10.1002/mmnd.191519150603

Nonfried A.F. 1891. Weitere Beiträge zur Käferfauna von Südasien und Neuguinea. Berliner Entomologische Zeitschrift 36 (2): 359-379.

Paulian R. 1961. Coléoptères Scarabéidés de l'Indochine (Rutélines et Cétonines). Annales de la Société Entomologique de France 130: 1-47 (225-271).

Pic M. 1928a. Coléoptères exotiques en partie nouveaux (suite). L'échange, Revue Linnéenne 44 (432): $7-8$.

Pic M. 1928b. Nouveautés diverses. Mélanges Exotico-Entomologiques 52: 4-5.

Ricchiardi E. \& Li S. 2015. Annotated checklist of Chinese mainland Dasyvalgus, with description of nine new species (Coleoptera Scarabaeidae Cetoniinae). Bollettino della Società Entomologica Italiana 147: 113-133. https://doi.org/10.4081/BollettinoSEI.2015.113

Schenkling S. 1922. Coleopterorum Catalogus, Pars 75: Scarabaeidae: Trichiinae, Valginae. W. Junk, Berlin.

Smith A.B.T., Hawks D.C. \& Heraty J.M. 2006. An overview of the classification and evolution of the major scarab beetle clades (Coleoptera: Scarabaeoidea) based on preliminary molecular analyses. Coleopterists Society Monograph 5: 34-46. https://doi.org/10.1649/0010065X(2006)60[35:AOOTCA]2.0.CO;2 
Manuscript received: 26 May 2016

Manuscript accepted: 4 December 2016

Published on: 1 August 2017

Topic editor: Gavin Broad

Desk editor: Natacha Beau

Printed versions of all papers are also deposited in the libraries of the institutes that are members of the EJT consortium: Muséum national d'Histoire naturelle, Paris, France; Botanic Garden Meise, Belgium; Royal Museum for Central Africa, Tervuren, Belgium; Natural History Museum, London, United Kingdom; Royal Belgian Institute of Natural Sciences, Brussels, Belgium; Natural History Museum of Denmark, Copenhagen, Denmark; Naturalis Biodiversity Center, Leiden, the Netherlands; Museo Nacional de Ciencias Naturales-CSIC, Madrid, Spain; Real Jardín Botánico de Madrid CSIC, Spain. 